\title{
LA NEGACIÓN DEL HOLOCAUSTO EN LA JURISPRUDENCIA DEL TRIBUNAL EUROPEO DE DERECHOS HUMANOS: LA ENDEBLE JUSTIFICACIÓN DE TIPOS PENALES CONTRARIOS A LA LIBERTAD DE EXPRESIÓN
}

\author{
POR \\ JUAN MARÍA BILBAO UBILLOS \\ Catedrático habilitado de Derecho Constitucional
}

Cuando hablamos de negacionismo o revisionismo histórico nos estamos refiriendo al discurso que consiste en cuestionar o negar la realidad del genocidio cometido por los nazis durante la II Guerra Mundial, con el propósito declarado de borrar de la memoria colectiva la huella de esa infamia. Y comprende la negación pura y simple o la puesta en duda o en tela de juicio tanto de la realidad del genocidio como de su amplitud o de las modalidades de ejecución.

Así, el discurso negacionista niega la política de exterminio nazi contra los judíos. No sólo la voluntad de exterminio del III Reich, sino la liquidación sistemática, masiva e industrial de la comunidad judía (la solución final no fue otra cosa que la expulsión de los judíos hacia el Este). Niega la existencia de cámaras de gas (serían en realidad lugares de desinfección de la ropa de los deportados) y el exterminio de enfermos mentales, gitanos y miembros de otras razas consideradas inferiores. En todo caso, la cifra de víctimas judías es mucho menor de lo que se dice. El genocidio es una invención de la propaganda aliada, princi- 
palmente sionista, un mito cuya fabricación se debe únicamente a la perversidad y avidez de los judíos.

Los litigios relacionados con la negación del holocausto («la mentira de Auschwitz») han recalado en diversas ocasiones en el Tribunal de Estrasburgo (casi siempre en la extinta Comisión Europea de Derechos Humanos). Al fin y al cabo, entre los Estados que han ratificado el Convenio Europeo de 1950 no son pocos los que en su ordenamiento interno han tipificado como delito la conducta consistente en negar o minimizar el exterminio sistemático de los judíos bajo el régimen nacional-socialista. En una valoración de conjunto, la jurisprudencia recaída en estos asuntos, en los que los demandantes invocan como derecho supuestamente vulnerado la libertad de expresión consagrada en el art. 10 del Convenio, no destaca precisamente por su solidez. No convencen sus apelaciones genéricas y apodícticas a los valores que subyacen al Convenio o a su espíritu. Se rehuye el terreno del art. 10, de la ponderación y los refinados test de proporcionalidad $^{1}$ y se recurre a la artillería (conceptual) de grueso calibre: la cláusula del abuso de derecho del art. 17 del CEDH. Una desmesura, porque no estamos ante situaciones excepcionales de crisis o peligro para la estabilidad de las democracias europeas que podrán justificar una drástica limitación de la libertad de expresión.

\section{DEMANDAS CONTRA ALEMANIA}

La libertad de expresión, consagrada en el artículo 5 de la Constitución, es uno de los derechos fundamentales más valiosos en el sistema constitucional alemán, pero no disfruta de la posición privilegiada, de superioridad o preferencia, que ha alcanzado en los Estados Unidos. De hecho, se admite expresamente en el propio precepto constitucional (al igual que en el art. 10.2 del Convenio Europeo) que su ejercicio está limitado por las leyes generales, las disposiciones legales sobre la protección de la juventud y el respeto al honor personal.

En realidad, en el ordenamiento alemán es la dignidad humana («inviolable» según el art. 1 de la Ley Fundamental), en conexión con el derecho al libre desarrollo de su personalidad (art. 2), el valor supremo del orden jurídico. Es un re-

${ }^{1}$ La Comisión o el Tribunal habrían podido argumentar que las condenas penales impuestas a los demandantes no constituían una violación del derecho consagrado en el art. 10. Estaríamos ante una injerencia en su libertad de expresión justificada de conformidad con el art. 10.2 del Convenio, puesto que persigue una finalidad legítima, como es la de luchar contra el antisemitismo y sancionar los comportamientos que atentan contra el orden público o la reputación de las personas. Y responde a los criterios de necesidad y proporcionalidad establecidos por la jurisprudencia del Tribunal. 
ducto intangible que se protege frente a cualquier agresión. Este énfasis se explica por el contexto histórico en el que se elaboró el texto, tras la Segunda Guerra Mundial y la traumática derrota del nazismo, cuya barbarie dejó una profunda huella en la sociedad alemana y en su cultura jurídica. Y pesa tanto esa tragedia en la memoria colectiva que los alemanes no parecen estar dispuestos a correr el riesgo de que surja un nuevo monstruo que pueda alimentarse de un exceso de tolerancia o de ingenuidad.

Por eso mismo, en Alemania se impuso el modelo de la «democracia militante» (streitbare Demokratie) ${ }^{2}$. Un modelo basado en la idea de que el Estado debe defender la democracia de sus enemigos, que no aceptan las reglas de juego democrático y pretenden subvertirlas. No puede haber libertad para los enemigos de la libertad. Así, la Constitución prohíbe la creación de asociaciones «cuyos objetivos sean contrarios a las leyes penales o se dirijan contra el orden constitucional o contra la idea de entendimiento entre los pueblos» (art. 9.2) y prevé la posibilidad de privar de los derechos fundamentales a quien abuse de las libertades constitucionales con el fin de combatir el orden constitucional liberal y democrático (art. 18). Y en su art. 21 prohíbe los partidos políticos que por sus objetivos declarados o por el comportamiento de sus afiliados, atenten o se propongan eliminar el orden constitucional liberal y democrático o poner en riesgo la existencia de la República Federal Alemana.

En este contexto hay que situar la represión penal del revisionismo histórico. El mismo espíritu que anida en el modelo de democracia militante es el que alienta o inspira la criminalización de la negación del Holocausto. Hasta la reforma de 1994, la negación del exterminio masivo de judíos bajo el régimen nacional-socialista se perseguía y castigaba como una injuria (art. 185) y, de forma más esporádica, como una difamación de la memoria de un difunto (art. 189) o un delito de incitación al odio (Volksverhetzung) o atentado contra la dignidad humana de partes de la población o de grupos identificados por su nacionalidad, raza, etnia o religión $(\operatorname{art} .130)^{3}$. Con penas, por tanto, no demasiado severas. La

${ }^{2}$ Vid. Ronald J. Krotoszynsky Jr., "A Comparative Perspective on the First Amendment: Free Speech, Militant Democracy and the Primacy of Dignity as a Preferred Constitutional Value in Germany», en Tulane Law Review, n. ${ }^{\circ} 78,2004$, pp. 78-124.

3 A la hora de aplicar este tipo, la jurisprudencia distinguía entre la simple negación del holocausto y la acusación a los judíos de haber fabricado una gran mentira. Así, negar el exterminio masivo de judíos en el curso del Tercer Reich («mistificación de Auschwitz») no sería, en sí mismo, un atentado a la dignidad humana (OLG Celle, 17 de febrero de 1982, NJW 1982, 1545), mientras que acusar a los judíos de haber inventado «la leyenda del exterminio» sí era un atentado contra la dignidad humana y constituía un delito de los previstos en el art. 130.1 y 2 del CP (BGH, de 26 de enero de 1983, NJW 1994, 1421). 
pena prevista en el art. 185 del CP para las injurias sin violencia es de un año de prisión como máximo o multa. El propio Tribunal Constitucional Federal avaló la aplicación del art. $185 \mathrm{CP}$ a los supuestos de negación del holocausto en su sentencia de 13 de abril de 1994: en estos casos, la condena por injurias no infringe la libertad de expresión.

La Ley de lucha contra la criminalidad (Verbrechensbeckämpfungsgesetz), de 28 de octubre de 1994, añadió un nuevo apartado al art. 130 estipulando que la negación, aprobación o minimización en público o en el curso de una reunión, de una manera susceptible de alterar la paz pública, del genocidio perpetrado bajo régimen nacional-socialista, será castigada con una pena de hasta 5 años de prisión o multa. $\mathrm{Y}$ esto se aplica también a las publicaciones con ese mismo contenido, cuya difusión se castiga con una pena de hasta tres años de prisión o multa. En realidad, el tipo específico responde más a razones político-simbólicas que a una ampliación del ámbito punible respecto de situación anterior, puesto que ya existía una jurisprudencia consolidada ${ }^{4}$. Lo más relevante es su definición como delito perseguible de oficio (por la propia Fiscalía), sin necesidad de denuncia previa por parte de los ofendidos.

En líneas generales, el art. 130, tal y como se ha interpretado jurisprudencialmente, parece exigir que la negación o banalización sea idónea para afectar a bienes jurídicos supraindividuales como la paz pública. No se castiga la simple negación de hechos históricos sino su significación social de agitación e incitación al enfrentamiento y a la eliminación de determinados grupos sociales especialmente vulnerables.

Pues bien, el primer pronunciamiento de los órganos que velan por la observancia del Convenio Europeo sobre resoluciones de tribunales alemanes en este tipo de controversias no se produjo como consecuencia de una condena penal. En su decisión de 16 de julio de 1982 en el asunto $X$ contra República Federal Alemana, la Comisión declaró inadmisible la demanda que traía causa de la prohibición, por orden judicial, de la exposición y venta de folletos en los que se afirmaba que el asesinato de millones de judíos bajo el Tercer Reich era una estafa sionista.

En 1975, el demandante había colgado de la valla de su jardín un tablón de anuncios en el que había clavado, entre otras publicaciones, varios folletos en los que se calificaba la masacre de seis millones de judíos de pura invención. Un ve-

${ }^{4}$ Esta ley vino precedida de tres importantes pronunciamientos del Tribunal Federal de Justicia (Bundesgerichtshof) y del Tribunal Constitucional Federal que pusieron de manifiesto las dificultades que venían detectándose en la aplicación de la legislación anterior y la necesidad de una tipificación más clara e inequívoca de esas conductas. 
cino de origen judío, cuyo abuelo había sido asesinado en el campo de concentración de Auschwitz, se sintió difamado por esos folletos. Después de haber obtenido una orden judicial provisional, interpuso una acción civil contra el demandante para poner fin a ese comportamiento. En abril de 1977, el tribunal regional de Mayence estimó fundada la demanda con arreglo a los arts. $1004 \mathrm{y}$ 823 (2) del Código Civil, en conexión con el art. 285 del Código Penal. Consideró probado que el demandante, miembro notorio de una organización política de derechas, era el responsable de la colocación de los folletos. Es verdad que los textos en cuestión no aludían personalmente ni al demandante ni a su abuelo, pero debían considerarse difamatorios respecto de todos los judíos perseguidos o asesinados bajo el Tercer Reich y sus parientes vivos. Este familiar, que podía interpretar que los folletos calificaban de mentira y estafa la trágica suerte de su abuelo, podía promover una acción por difamación contra el demandante. Y podía exigir que éste se abstuviera de hacer ese género de declaraciones. $\mathrm{Al}$ fin y al cabo, numerosos documentos incontestables han probado que realmente fueron millones los judíos muertos como resultado de la persecución emprendida por las autoridades nacional-socialistas. El tribunal decidió prohibir al demandante repetir esas declaraciones bajo pena de multa o prisión.

En mayo de 1978, el Tribunal de Apelación de Coblenza estimó el recurso del demandante, al entender que el vecino que le demandó carecía de legitimación para actuar contra él. Los folletos no se dirigían a él ni personalmente ni como miembro del grupo de judíos que podían sentirse ultrajados, de acuerdo con la jurisprudencia del Tribunal Federal de Justicia. Los folletos no difamaban a los judíos en cuanto tales sino sólo a las personas que profesan determinadas opiniones sobre la persecución de los judíos bajo el Tercer Reich.

El vecino apeló a su vez ante el Tribunal Federal de Justicia (Bundesgerichtshof) y esta vez su recurso sí prosperó. En su sentencia de septiembre de 1979, el Alto Tribunal quiso recalcar en primer lugar que «quien niega el hecho histórico del asesinato de los judíos bajo el Tercer Reich no puede invocar la libertad de expresión reconocida en el art. 5.1 de la Ley Fundamental, porque esta libertad no comprende el derecho a formular declaraciones erróneas». No es una cuestión opinable: «la masacre de millones de judíos es un hecho establecido por documentos incontestables». El Tribunal rechazó el argumento del demandante según el cual los folletos en cuestión no hacían otra cosa que criticar las estimaciones exageradas acerca del número de judíos asesinados. Los folletos calificaban claramente de mentira el hecho mismo del asesinato de millones de judíos y negaban por tanto la suerte inhumana que sufrieron los judíos en razón simplemente de su origen étnico. No se trata de una crítica objetiva de carácter historiográfico desprovista de cualquier intención insultante para alguien. Constituye, por el 
contrario, una falta de respeto para todas las víctimas judías de la persecución nazi.

El Bundesgerichtshof se apoyó en los principios jurisprudenciales previamente establecidos en materia de difamación de los judíos: en razón del particular contexto histórico, toda persona que pertenece a ese grupo étnico puede considerarse difamada por un ataque dirigido contra el grupo en cuanto tal, con independencia de que haya sufrido personalmente la persecución o haya vivido durante ese periodo (en este caso, al haber nacido el actor civil en 1930, sí resultaba afectado directamente por la legislación racial de Nuremberg y no hay duda de que formaba parte del grupo). Todo intento de justificar, atenuar o negar el destino de los judíos bajo el Tercer Reich le afecta personalmente y le asiste el derecho a considerarse difamado por ese género de declaraciones. Así pues, el TFJ restablece el criterio sentado en primera instancia 5 .

El demandante presentó entonces una queja constitucional invocando en especial la libertad de expresión garantizada por el art. 5.1 de la Ley Fundamental. En marzo de 1980, una Sala compuesta por tres Jueces del Tribunal Constitucional Federal decidió no admitir a trámite el recurso, al entender que el TFJ había concluido con toda razón que las declaraciones en cuestión eran inexactas y no se beneficiaban de la protección que brinda el citado artículo 5 .

En su demanda ante la Comisión Europea de Derechos Humanos, el demandante invoca los derechos que le garantizan los arts. 2, 3, 5, 6, 7, 8, 9, 10, 14 y 17 del Convenio. Alega en particular que las decisiones judiciales adoptadas en su contra equivalen a suprimir la verdad por razones políticas. Se remite a algunas obras publicadas como prueba de que existen trabajos científicos que niegan los asertos de la historiografía oficial. Rechazar esos documentos sin indagación alguna es una muestra evidente, según él, de que los magistrados no eran independientes ni imparciales y le negaron las garantías de un proceso justo ${ }^{6}$.

${ }^{5}$ Después de la sentencia del Bundesgerichtshof, se abrieron diligencias penales contra el demandante por incitación al odio racial (art. $130 \mathrm{CP}$ ), siendo declarado culpable y condenado a un año de prisión.

${ }^{6}$ La Comisión examinará las quejas referidas al procedimiento civil que desembocó en la prohibición de reiterar ese tipo de declaraciones. No puede examinar la ulterior condena penal del demandante por incitación al odio racial, fundada aparentemente en los mismos hechos, porque éste no ha demostrado que hubiera agotado previamente todos los recursos internos (en este punto, la demanda es inadmisible). En cuanto al procedimiento civil, tampoco ha agotado las vías internas de impugnación en relación con algunas de las quejas que ahora formula ante la Comisión. Por esa razón, ésta se limita a examinar, por un lado, las quejas relacionadas con el art. 10 del Convenio, respecto de las cuales sí se han agotado los recursos internos, y por otro, las fundadas en el art. 6.1. 
Para la Comisión, no cabe duda de que en este caso se produjo una injerencia en la libertad de expresión del demandante, puesto que se le prohibió exhibir públicamente unos folletos que encerraban un determinado contenido. La restricción impuesta estaba prevista en la legislación alemana, tal y como ésta es interpretada por los tribunales alemanes. Esta jurisprudencia se funda desde hace mucho tiempo en el principio de que los judíos, en tanto que grupo, pueden sentirse ofendidos y cada miembro de esa comunidad puede considerarse difamado por declaraciones insultantes dirigidas contra los judíos en general.

A juicio de la Comisión, no era «ni arbitrario, ni irrazonable considerar los folletos expuestos por el demandante como un ataque difamatorio dirigido contra la comunidad judía en general y contra cada uno de sus miembros en particular». Al calificar de mentira y estafa sionista el hecho histórico del asesinato de millones de judíos, como el propio autor reconoce, «los folletos en cuestión no sólo dan una imagen deformada de hechos históricos, sino que también empañan la reputación de todos aquellos a los que se califica de mentirosos y estafadores». La Comisión justifica además la restricción impuesta a la libertad de expresión del demandante, en la medida en que no sólo respondía a un objetivo legítimo reconocido por el Convenio (la protección de la reputación de los demás) sino que podía ser considerada también como necesaria en una sociedad democrática, que descansa en los principios de tolerancia y amplitud de espíritu que brillan por su ausencia en los folletos en cuestión. Para la Comisión, «resulta particularmente indicado salvaguardar esos principios con respecto a grupos que han sufrido históricamente discriminación». Es más, «el hecho de limitar a ciertos grupos concretos, en especial a los judíos, la protección colectiva contra la difamación se apoya en consideraciones objetivas y no implica ningún elemento de discriminación contraria al art. 14 del Convenio». En definitiva, la queja del demandante relativa a la presunta violación de su derecho a la libertad de expresión está manifiestamente mal fundada, en el sentido del art. 27.2 del Convenio.

En cuanto a la posible violación del art. 6, la Comisión constata que, en la medida en que el demandante se queja de que los tribunales no tuvieron en cuenta los elementos de prueba por él proporcionados sobre los hechos históricos litigiosos, no hay apariencia alguna de violación de los principios de un proceso justo. La restricción impuesta al demandante se limitaba a los asertos que negaban el hecho histórico del asesinato de millones de judíos. Este hecho histórico no es sólo un hecho notorio, establecido con certeza mediante pruebas abrumadoras de todo tipo, sino que incluso ha sido reconocido por el propio demandante. Los intentos de justificación por parte del interesado aduciendo que los folletos se limitaban a criticar las estimaciones exageradas de víctimas (la 
cifra) no se corresponden con el contenido de los folletos. El Tribunal Federal de Justicia precisó que la ley autoriza a criticar objetivamente la historiografía, en particular, la evaluación del número de judíos asesinados. Sin embargo, los hechos de la causa no obligan en absoluto a recabar pruebas a este respecto porque es la negación como tal del hecho histórico lo que se considera difamatorio. A diferencia del tipo penal de la calumnia (art. 186 CP), la difamación (art. 185 $\mathrm{CP})$ no consiste en afirmar determinados hechos cuya veracidad puede ser probada o no. Constituye un juicio de valor expresado de forma injuriosa que no es posible refutar mediante prueba en contrario ${ }^{7}$.

La Comisión volvió a ocuparse de esta cuestión en su decisión de 6 de septiembre de 1995, en el caso Otto E.F.A. Remer contra Alemania, que declaró inadmisible la demanda presentada en 1994 por el antiguo nazi, general retirado y conocido negacionista Otto Ernst Remer, condenado en Alemania por incitación al odio racial.

En efecto, el 22 de octubre de 1992 el Tribunal regional (Landgericht) de Schweinfurt había condenado al demandante, en aplicación de los art. 130(1) y 131(1) del Código Penal alemán, a una pena de 1 año y 10 meses de prisión. El Tribunal consideró que el demandante era el editor de una publicación impresa de forma irregular titulada "Remer Depeschen» y autor él mismo de algunos de los artículos. En su sentencia, el Tribunal regional describía el contenido de cinco de los números de la revista en los años 1991 y 1992 de los que se distribuyeron 80.000 ejemplares. En estos números la revista incluía artículos que sugerían que las cámaras de gas de los campos de concentración durante el régimen nazi nunca existieron. En otros se daba cuenta de los esfuerzos del demandante por informar al público sobre las mentiras en torno a la supuesta eliminación mediante gas tóxico de un millón de judíos en Auschwitz. O se condenaba la política alemana en relación con Israel y se criticaba el tratamiento preferente que se concedía a los solicitantes de asilo, a los gitanos y los traficantes de drogas, y la destrucción de Alemania como resultado de la inmigración de extranjeros.

7 Como se trataba en este caso de una acción civil resultan de aplicación los principios del procedimiento civil, y en especial el principio dispositivo (el tribunal ha de atenerse a los términos de la demanda). En este caso, el demandado no alegó que los folletos expuestos por el demandante fuesen calumniosos por estar fundados en datos erróneos. Se limitó a hacer valer que el conjunto era difamatorio contra los judíos en general y contra él mismo en particular y esa fue la única cuestión litigiosa que se planteó ante los tribunales. Estos no fueron llamados a indagar acerca de si los datos en cuestión eran o no exactos sino sólo a dilucidar si tenían o no carácter difamatorio. La Comisión no aprecia pues ningún indicio o apariencia de violación del derecho a un proceso justo reconocido por el art. 6.1 del Convenio. En este punto, la demanda está también manifiestamente mal fundada y se declara inadmisible. 
El Tribunal consideró que las publicaciones en cuestión hacían creer o daban a entender que bajo el régimen nazi no existieron las cámaras de gas para asesinar judíos y que esa mentira había sido inventada por los judíos con el fin de obtener dinero del Gobierno alemán. A su juicio, el demandante conocía la verdad histórica, por lo demás evidente, sobre el asesinato de los judíos en las cámaras de gas de campos de concentración como Auschwitz. Pero él no pretendía solamente abrir un debate público sobre este asunto, sino que también trataba de instigar el odio contra los judíos.

Según el Tribunal, todo el mundo sabe, porque es de dominio público que los contenidos de esos artículos, especialmente la negación de la existencia de las cámaras de gas y la muerte en ellas de millones de judíos, así como la afirmación de que los judíos tratan de extorsionar al pueblo alemán, son falsos y que se trata de hechos históricamente probados. En este sentido, se hace referencia a la jurisprudencia del Tribunal Constitucional Federal en relación con el término "common Knowledge» (offenkundig) y las voces relativas a estas cuestiones (cámaras de gas, campos de concentración, Auschwitz) en diversas enciclopedias.

El 16 de noviembre de 1993, el Tribunal Federal de Justicia rechazó el recurso de apelación del demandante. En su sentencia, confirmó el razonamiento del tribunal de primera instancia en el sentido de que el asesinato masivo de judíos en las cámaras de gas de los campos de concentración estaba históricamente probado y era por ello de dominio público. No había necesidad pues de probar estos hechos. Así se ha establecido en la jurisprudencia del Tribunal Constitucional y de los Tribunales de Apelación.

El alto Tribunal rechaza también el argumento de la defensa de que las publicaciones estaban al servicio y tenían como objetivo la investigación histórica. Observa que los arts. 130 y 131 del Código Penal alemán tratan de asegurar la coexistencia pacífica de la población en Alemania. Todo aquel que basándose en las ideas del nacional-socialismo incite al odio contra partes o sectores de la población haciendo que hechos falsos sean de común conocimiento y acusando a esos grupos de mentir y extorsionar les está retratando o describiendo como un colectivo particularmente abominable. Con mayor razón cuando el trágico destino de los judíos bajo el régimen nazi se presenta como una invención y esa afirmación se combina con la imputación de una supuesta extorsión. En febrero de 1994, el Tribunal de Karlsruhe decidió no admitir a trámite el recurso de amparo (Verfassungsbeschwerde) promovido por el demandante.

En su demanda ante el Tribunal de Estrasburgo, Remer alega que su condena es de naturaleza política e infringe su derecho a la libertad de pensamiento y de conciencia y a la libertad de expresión, en lo que concierne a la afirmación, a su juicio verdadera, de la inexistencia de cámaras de gas en los campos de 
concentración alemanes. Invoca pues los arts. 9 y $10 \mathrm{CEDH}$ (también el art. 3, por considerar que el ingreso en prisión a su edad es una pena inhumana; y el art. 6, por supuesta infracción del derecho a un juicio justo y de la presunción de inocencia).

La Comisión entiende que la queja principal del demandante es la de haber sido condenado por difundir determinadas publicaciones, por lo que examina sus alegaciones bajo la perspectiva del art. $10 \mathrm{CEDH}$. No ofrece dudas que estamos ante una medida que entraña una injerencia en el ejercicio de la libertad de expresión. Y que es una interferencia prevista por la ley. La medida persigue además una finalidad legítima a la luz del art. 10.2 del Convenio: la preservación del orden público y la prevención del delito y la protección de la reputación y de los derechos de los demás.

Queda por averiguar si la condena fue «necesaria en una sociedad democrática». Recuerda la Comisión en el contexto del art. 10.2 el adjetivo «necesaria» implica la existencia de una «necesidad socialmente apremiante». A su juicio, las disposiciones del Código Penal en cuestión y su aplicación en este caso tratan de garantizar la coexistencia pacífica de la población en la RFA. E invoca en este sentido el art. 17 del CEDH, que excluye la posibilidad de ampararse en las normas del Convenio para desarrollar actividades dirigidas a destruir el sistema de derechos y libertades consagrado en el mismo, entre otros, la libertad de expresión.

Atendiendo a las circunstancias del caso, la Comisión destaca las detalladas consideraciones del Tribunal regional acerca del contenido de las publicaciones del demandante en las que trata de incitar al odio contra los judíos. Y se hace eco también de la sentencia del Tribunal Federal de Justicia. Para la Comisión, esos escritos son contrarios a una de las ideas básicas del Convenio, tal y como se expresa en su preámbulo, a saber, la justicia y la paz, y entraña además una discriminación religiosa y racial. El público interés en la prevención del crimen y del desorden en la sociedad alemana y las exigencias de protección de la reputación y los derechos pesa más en una sociedad democrática que la libertad del demandante para divulgar publicaciones que niegan el asesinato de los judíos en las cámaras de gas y sus acusaciones de extorsión. En esas circunstancias, existen razones relevantes y suficientes para la condena del demandante. La sentencia era «necesaria en una sociedad democrática». No hay por tanto en apariencia una violación del derecho del demandante consagrado en art. $10 \mathrm{CEDH}$. De donde se sigue que esta alegación es manifiestamente infundada. A la misma conclusión llega respecto de las demás quejas. Por todo ello, la Comisión, por unanimidad, declara la demanda inadmisible. 


\section{DEMANDAS CONTRA AUSTRIA}

En Austria está vigente la Ley de Prohibición del Nacional-Socialismo (Verbotsgesetz) que castiga a quienes realicen actividades inspiradas en ideas nacionalsocialistas. Una primera versión de esta Ley fue promulgada el 8 de mayo de 1945. Disponía la prohibición del Partido nazi (el Partido Obrero Alemán Nacional-Socialista) y preveía la pena capital incluso para quien se mantuviera como miembro, actuase con ese fin o sirviese a sus objetivos. La Ley de reforma de 6 de febrero de 1947 (la Nationalsozialistengesetz) concretó las infracciones penales previstas por la Ley de Prohibición y sustituyó la infracción general por una serie de cláusulas, en particular las enunciadas en los arts. 3a a 3g. En 1968, la pena capital fue abolida. La modificación más reciente data de 1992: introduce el art. 3h, que sanciona expresamente la negación o banalización de los crímenes nacional-socialistas. Siendo más precisos, castiga a quien niegue, banalice groseramente, apruebe o trate de justificar el genocidio u otros crímenes contra la humanidad del régimen nacional-socialista en una publicación, una emisión o cualquier otro medio de comunicación, o por cualquier otro medio publico accesible a un gran número de personas.

$\mathrm{Al}$ insertar esta disposición, el legislador quiso mostrar claramente que el exterminio masivo de los judíos fue un hecho histórico universalmente admitido cuya prueba no tiene que ser aportada ante los tribunales. Es más, la reforma redujo las penas mínimas para todos los delitos incluidos en la Ley de Prohibición dejando intactos los límites superiores ${ }^{8}$. Esta reforma estaba destinada a reducir la aversión de los jurados a condenar en los casos en los que consideraban al sospechoso culpable, al estimar que la sentencia podría ser demasiado dura. Este precepto fue el que sirvió para condenar al historiador británico David Irving en febrero de 2006.

La doctrina de la Comisión en torno al tratamiento de esta cuestión en Austria se establece por primera vez en su decisión de inadmisión de 12 de octubre de 1989, dictada en el asunto B.H., M.W., H.P. y G.K. contra Austria.

Los demandantes, cuatro ciudadanos austriacos, se quejan del procedimiento abierto contra ellos y otras personas por un tribunal de su país en aplicación de la Ley de Prohibición. La investigación comenzó en 1978 y la acusación se formuló finalmente en febrero de 1983. En abril de 1984 el Tribunal Penal del Land de Viena condenó a los cuatro demandantes por uno o varios de

${ }^{8}$ La pena prevista es de 1 a 10 años de prisión. Y hasta 20 años si el autor de la infracción cometida es particularmente peligroso. 
los delitos previstos en la sección 3g de la citada ley a penas de 9, 3, 18 y 12 meses de prisión condicional respectivamente ${ }^{10}$. El Tribunal Supremo confirmó las condenas mediante sentencia de 25 de junio de 1986, aunque redujo la del tercer demandante a quince meses. Y rechazó, en particular, los distintos motivos de nulidad esgrimidos por los demandantes.

Los demandantes denuncian ante la Comisión la violación de los derechos reconocidos en los artículos 6, 7, 10, 14 y 18 del Convenio ${ }^{11}$. Los demandantes

${ }^{9}$ La sección 3g) dispone lo siguiente: «Quien realice actividades inspiradas en las ideas del Nacional-Socialismo de una manera que no encaje dentro del ámbito de las secciones $3 \mathrm{a}$ a $3 \mathrm{f}$ podrá ser castigado con una pena de prisión entre 5 y 10 años y si el infractor o su actividad son particularmente peligrosos a una pena de prisión de hasta 20 años, a no ser que el acto sea castigado por una norma diferente que prevea una sanción más severa...».

10 Tal y como prevé el Código de Procedimiento Criminal en relación con el procedimiento ante el tribunal de primera instancia, la condena no fue motivada. A la vista de las detalladas cuestiones planteadas al jurado parece que los demandantes fueron declarados culpables de varios actos relacionados con su condición de miembros y dirigentes de dos organizaciones políticas de extrema derecha llamadas "Aktion Neue Rechte» (ANR) y "Nationalistischer Bund Nordland» (NBN), que desarrollaban actividades inspiradas en la ideología nacional-socialista. Estas actividades incluían, entre otras cosas, la preparación y promoción de ciertas publicaciones, como panfletos en los que se afirmaba que el asesinato de 6 millones de judíos por los nazis era mentira; el programa del partido ANR basado en las diferencias biológicas entre individuos, pueblos, y razas, el principio del elitismo, la unidad de la nación alemana y su «Lebensraum» (espacio vital) que comprendería territorios extranjeros ocupados, el rechazo del concepto de una «nación austriaca» y el reconocimiento del carácter alemán de su territorio; publicaciones que llaman al boicot de la Fiesta nacional de Austria, que se presenta como una imposición del Tratado, que prohíbe la anexión (Anschluss) y niega el derecho de autodeterminación de los austriacos; publicaciones que invitan a celebrar el día de la unidad alemana en Austria y presentan la noción de una nación austriaca como una mentira y proponen introducir las típicas canciones nazis, etc. A estas actividades había que añadir la participación en algunas manifestaciones (entre otras, la celebración del 90 cumpleaños de Hitler en Braunau o una manifestación contra el Tratado del Estado austriaco), la realización de ejercicios paramilitares, el uso de uniformes que recuerdan la indumentaria nazi o la repetición de consignas o expresiones nazis como «Sieg Heil». El juez que presidió el tribunal recordó en las instrucciones legales dadas al jurado que Austria había formulado una reserva respecto de la compatibilidad de la Ley de Prohibición con los artículos 10 y 11 del Convenio (información que resultó errónea).

${ }^{11}$ En relación con el principio de legalidad consagrado en el art. 7 del Convenio, los demandantes aducen que la sección $3 \mathrm{~g}$ de la Ley de Prohibición del Nacional-Socialismo no es una norma válida del ordenamiento austriaco. Fue dictada mediante un procedimiento ilícito y derogada por la legislación constitucional posterior, incluyendo el art. 10 del Convenio. Además, dicho precepto no es suficientemente preciso para servir de base a una condena penal. Su vaguedad y amplitud permite su aplicación arbitraria a actos no inspirados en la ideología nacional-socialista sino en el pensamiento nacionalista alemán compatible con el sistema democrático austriaco. La Comisión observa, sin embargo, que el Tribunal Supremo austriaco ya había confirmado la vali- 
alegan, por lo que ahora importa, que la sección 3g, tal y como ha sido aplicada en este caso, constituye una injerencia injustificada en su libertad de expresión, en la medida en que prevé una sanción desproporcionada para la expresión de ciertas opiniones, en particular sobre hechos históricos que deberían ser discutidos libremente en una sociedad democrática. Y formulan igualmente una queja por discriminación contraria al art. 14 del Convenio porque se les persigue por ser austriacos apegados al nacionalismo alemán, pero no se han previsto sanciones similares para aquellos que niegan, minimizan o defienden los crímenes comunistas o los crímenes cometidos por los Aliados en la II Guerra Mundial. Invocan por último el art. 18 del Convenio alegando que las restricciones impuestas a su libertad de expresión se aplicaron para lograr otras finalidades distintas de las autorizadas por el Convenio, y más concretamente para suprimir el pensamiento nacionalista alemán y las publicaciones que lo difunden, que no están prohibidas.

La Comisión no encuentra indicios de una violación de las disposiciones invocadas. Y hace la siguiente afirmación: «La prohibición de actividades que impliquen la expresión de ideas nacional-socialistas es ilegal en Austria, y en vista del pasado histórico que constituye el immediato background del propio Convenio, puede justificarse como una medida necesaria en una sociedad democrática para salvaguardar la seguridad nacional y la integridad territorial así como para prevenir el crimen». Estaría por tanto amparada por el artículo 10.2 del Convenio. En respuesta a los reproches basados en una supuesta discriminación, la Comisión replica que el hecho de que las actividades nacional-socialistas sean tratadas en la sección $3 \mathrm{~g}$ de manera diferente a las de otros grupos políticos tiene una justificación objetiva y razonable en la experiencia histórica de Austria durante la era del Nacional-Socialismo, en las obligaciones contraídas en

dez y la constitucionalidad de la sección 3g, lo que es primordialmente un asunto de Derecho interno. Tal decisión no es para la Comisión ni arbitraria ni irrazonable. En el Tratado de 1955 Austria se comprometió a mantener la legislación que prohibía las actividades nacional-socialistas. Respecto de la supuesta falta de precisión del precepto, es verdad que la referencia a las «actividades inspiradas en las ideas nacional-socialistas» es un poco vaga. Pero es que el legislador quiso prohibir todo tipo de actividades nacional-socialistas. El alcance de la norma se limita al Nacional-Socialismo como una ideología histórica. Es un concepto suficientemente preciso que permite distinguir entre esa ideología y otro tipo de pensamiento nacionalista. Señala además la Comisión que la doctrina y la jurisprudencia austriacas han desarrollado criterios que hacen suficientemente accesible y previsible la norma aplicable. Así, el jurado era capaz en este caso de distinguir entre actividades de los demandantes que podían considerarse o no como inspiradas en las ideas nacional-socialistas. La Comisión no aprecia la existencia de indicios de una violación del art. 7 del Convenio y por tanto esta queja se considera manifiestamente infundada. 
el Tratado de 1955 y en el peligro que tales actividades basadas en el pensamiento nacional-socialista pueden constituir para la sociedad austriaca.

La Comisión se refiere también al art. 17 del Convenio ${ }^{12}$ y advierte que el nacional-socialismo es «una doctrina totalitaria incompatible con la democracia y los derechos humanos» y sus seguidores persiguen indudablemente objetivos del tipo de los enunciados en el citado precepto. No hay por tanto apariencia alguna de discriminación contraria al art. 14 del Convenio.

Así pues, las quejas de los demandantes basadas en los arts. 10, 14 y 18 del Convenio son manifiestamente infundadas. La Comisión analiza seguidamente la presunta violación del art. 6, y llega a la misma conclusión, por lo que declarará inadmisible la demanda.

Del mismo signo (inadmisibilidad) es la decisión fechada el 2 de septiembre de 1994 en el asunto Walter Ochensberger contra Austria. El demandante es un ciudadano austriaco, procesado en mayo de 1991 por haber editado, publicado y distribuido en 1989 y 1990 una serie de artículos en la revista «Sieg-AJPressedienst» que, dado su contenido, constituían una «actividad nacional-socialista» en el sentido de la sección $3 \mathrm{~g}$ de la Ley de Prohibición (Verbotsgesetz). A finales de 1991 se celebró el juicio oral contra el demandante ante el Tribunal regional de Feldkrich y con jurado ${ }^{13}$.

El 9 de diciembre el demandante fue condenado como autor de un delito previsto en la sección $3 \mathrm{~g}$ de la Ley de Prohibición a una pena de tres años de pri-

12 Se apoya en la interpretación que ella misma hizo de este precepto en Kühnen contra RFA, decisión de 12 de mayo de1988. Dijo entonces que tal disposición "cubre esencialmente aquellos derechos que pudieran facilitar el intento de hacer derivar de ellos un derecho a implicarse personalmente en actividades destinadas a destruir alguno de los derechos y libertades consagrados en el Convenio». La Comisión ha afirmado en repetidas ocasiones que la libertad de expresión contemplada en el art. 10 del Convenio no puede ser invocada en un sentido contrario al art. 17.

${ }^{13}$ En la sesión de 29 de noviembre, la Fiscalía, de acuerdo con la defensa, señaló determinadas partes de los artículos para ser leídas ante el tribunal. Se repartieron entre los miembros del jurado copias de esos párrafos marcados. En esa misma sesión, el abogado del demandante formuló numerosas preguntas y propuso que se recabaran informes de expertos en historia contemporánea, teología, etnología, antropología, ecología, periodismo e historia económica. Las opiniones de estos expertos podrían confirmar la veracidad de los artículos en cuestión, en particular de los peligros de una inmigración ilimitada y sin control para la población local y su pureza étnica, de los abusos sistemáticos de los judíos en los Estados Unidos, de los culpables del estallido de la II Guerra Mundial y de los objetivos y funcionamiento de los campos de concentración bajo el Tercer Reich. Esta petición fue rechazada por el tribunal con el argumento de que se formulaba en términos demasiado generales como para permitir la obtención de pruebas específicas y en todo caso esas opiniones eran irrelevantes en relación con cuestiones de interpretación legal que implican juicios de valor. Además, respecto de los hechos históricos, las pruebas solicitadas por el demandante conciernen a asuntos de dominio público o general conocimiento que no requieren prueba alguna. 
sión. El Tribunal consideró que durante los años 1989 y 1990 el demandante había desarrollado actividades nacional-socialistas al editar, publicar y distribuir los artículos especificados en el juicio en la revista «Sieg-AJ-Presse-Dienst». Estos artículos, por su presentación, dibujos y contenido, incitaban a la gente al odio, al antisemitismo y a la xenofobia, glorificaban la raza alemana y negaban la soberanía de Austria. Presentaban también de una manera propagandística, sesgada, las acciones e intenciones del Tercer Reich, justificando en particular la construcción de campos de concentración, minimizando los asesinatos cometidos en ellos y poniendo el énfasis en los cometidos por los aliados. En julio de 1992, el Tribunal Supremo rechazó la petición de nulidad formulada por el demandante, pero estimó su recurso de apelación y redujo la condena a dos años de prisión ${ }^{14}$.

Entre otras quejas (basadas en el art. 6), el demandante denuncia a la luz del art. 10 del Convenio que su condena vulneró su derecho a la libertad de expresión. Sostiene que en un Estado democrático basado en el imperio de la ley actividades políticas como las que él desarrollaba no podían ser sancionadas y que las disposiciones relativas a la prohibición de actividades que implican la expresión de ideas nacional-socialistas no son suficientemente precisas.

La Comisión admite que la condena impuesta al demandante constituye una injerencia en su libertad de expresión, que podrían violar el art. 10 si no estuviera justificada con arreglo al art. 10.2. Se trata en todo caso de una medida prevista por la ley. Y se remite a la doctrina sentada en la decisión anterior. Apelando de nuevo al art. 17 del Convenio, y a la vista de las circunstancias del caso, la Comisión dice que el demandante había intentado utilizar la libertad de información reconocida en el art. 10 como un instrumento para realizar actividades que son contrarias al texto y el espíritu del Convenio y que, si se aceptasen, podrían contribuir a la destrucción de los derechos y libertades consagrados en

${ }^{14}$ En cuanto a la petición de informes de expertos en orden a probar los peligros de una política de inmigración descontrolada para la población austriaca que el demandante había denunciado o la conducta de los judíos en los Estados Unidos, el Alto Tribunal consideró que eran irrelevantes para la acusación de incitación al odio racial. Tampoco los informes de expertos en historia para probar que los artículos sobre los campos de concentración se ajustaban a la realidad eran relevantes en relación con los cargos de incitación al odio racial por presentar de una forma propagandística y positiva los actos de violencia y las violaciones de derechos humanos cometidas por el régimen nacional-socialista y minimizar los crímenes cometidos en los campos de concentración. La solicitud de práctica de pruebas para intentar acreditar que la petición del «Anschluss» por parte de Austria para integrarse en el gran Estado alemán y que la acusación de antisemitismo y de oposición a una inmigración a gran escala no forma parte de la típica ideología nacional-socialista, resulta igualmente irrelevante de cara a la acusación. Es de dominio público y no precisa ninguna actividad probatoria que al antisemitismo no es una idea exclusiva del nacional-socialismo y que ya hubo reivindicaciones de "Anschluss» tras la I Guerra Mundial. 
el Convenio. La Comisión concluye que la interferencia en la libertad de expresión del demandante puede considerarse «necesaria en una sociedad democrática» en los términos del art. 10.2. En consecuencia, esta parte de la demanda resulta manifiestamente infundada. Dado que llega a la misma conclusión respecto de la alegada vulneración del art. 6, la Comisión, otra vez por unanimidad, declara inadmisible la demanda.

Pocas novedades encierra la decisión de 9 de septiembre de 1998 en el asunto Herwig Nachtmann contra Austria. Mediante sentencia de 8 de agosto de 1995, el Tribunal regional penal de Graz, en un proceso con jurado, había condenado al demandante por actividades nacional-socialistas en el sentido de la sección 3h de la Ley de Prohibición a una pena de multa y 10 meses de prisión. El tribunal consideró que el demandante, como máximo dirigente del equipo editorial de la revista "Aula, Das freiheitliche Magazin», era responsable de la publicación en la misma de un artículo titulado «Derecho natural aplicado a nazis $y$ antifascistas». En este artículo, a juicio del tribunal, se negaban y minimizaban groseramente el genocidio y otros crímenes nacional-socialistas. El tribunal analizó detalladamente las afirmaciones que insinuaban que el número de víctimas de los asesinatos masivos, de judíos en particular, mediante gas tóxico y cremación era muy exagerado y técnicamente imposible.

El demandante recurrió esa decisión y mediante sentencia de 21 de mayo de 1996, el Tribunal Supremo rechazó la petición de nulidad, pero estimó la apelación reduciendo la cuantía de la multa y la pena de prisión, que se rebaja a nueve meses.

Entre otras presuntas infracciones, Nachtmann alega en la demanda dirigida a la Comisión que la condena impuesta por los tribunales austriacos viola su derecho a la libertad de expresión garantizado por el art. 10 del Convenio, así como su libertad de pensamiento y conciencia. A su juicio, la opinión expresada en el citado artículo a acontecimientos históricos deplorables y la discusión sobre estos asuntos no debería ser castigada.

La Comisión se limita a constatar que, según el tribunal de Graz, la publicación en cuestión niega y minimiza groseramente los asesinatos masivos y otros crímenes cometidos bajo el régimen nacional-socialista. Esta conclusión, confirmada posteriormente por el Tribunal Supremo, no constituye una arbitrariedad. Es más, la Comisión recuerda que ya afirmó tempranamente que el nacional-socialismo es una doctrina totalitaria incompatible con la democracia y los derechos humanos y que sus seguidores persiguen indudablemente objetivos del tipo de los mencionados en el art. 17. La Comisión llega así a la conclusión de que la injerencia en cuestión puede considerarse como «necesaria en una sociedad democrática». 
La última de las decisiones que se reseñan en este apartado, la dictada por el propio Tribunal Europeo (una vez extinguida la Comisión) el 1 de febrero de 2000 en el asunto H.J. Schimanek contra Austria, inadmite la demanda presentada por un ciudadano austriaco, condenado con arreglo a la sección 3a (2) de la Verbotsgesetz $z^{15}$ a una pena de 15 años de prisión (sentencia del Tribunal penal del Land de Viena de 31 de marzo de 1995).

El jurado consideró que el demandante, en tanto que líder de una asociación, y entre otras actividades, había reclutado nuevos miembros, había organizado reuniones especiales en las que los miembros de la asociación se familiarizaban con una visión de la historia que glorificaba a los dictadores del Tercer Reich, su ejército, las SA y las SS, negando al mismo tiempo el asesinato sistemático mediante gas tóxico bajo ese régimen, y que había organizado la distribución de panfletos con un contenido similar. Además, el jurado consideró probado que el demandante había organizado a finales del año 1987 campos de entrenamiento paramilitar (Wehrsportübung) reuniendo a miembros uniformados de diferentes asociaciones agrupadas en una organización de extrema-derecha, la «Volkstreue Ausserparlamentarische Opposition» (VAPO), con la finalidad de estrechar los lazos de solidaridad entre los participantes, reforzar su preparación táctica de cara a posibles conflictos violentos, crear una unidad militar que pudiera imponer «mediante el uso de la fuerza si fuese necesario» los objetivos de la VAPO, más concretamente la toma del poder en Austria y la simultánea incorporación de Austria en la Gran Alemania (Grossdeutschland). Al dictar la sentencia, el tribunal tuvo en cuenta la confesión del demandante como una circunstancia atenuante, aunque su posición de dirigente de las mencionadas organizaciones, sus múltiples actividades y el adoctrinamiento de un gran número de jóvenes en las ideas nacional-socialistas se consideraron como circunstancias agravantes de la responsabilidad. El 22 de noviembre de 1995 el Tribunal Supremo confirmó la condena aunque redujo la pena a 8 años de prisión.

El demandante invoca, entre otros, los artículos 9 y 10 del Convenio, al entender que la sección 3a (2) de la Ley de Prohibición es una disposición inne-

${ }^{15}$ La sección 3a (2) de la Ley de Prohibición, cuya redacción fue modificada en 1992, dice: «Las siguientes personas podrían ser culpables de un delito y ser sancionadas con una pena de diez a veinte años de prisión o en el caso de que el infractor o la actividad se considere particularmente peligrosa, a cadena perpetua: 1 ... 2. Quien funde una asociación que se proponga, mediante las actividades de sus miembros inspiradas en las ideas nacional-socialistas, socavar la autonomía y la independencia de la República austriaca o subvertir el orden público y la reconstrucción de Austria, o bien desempeñe una función de dirigente en una asociación de este tipo». Antes de la reforma, que entró en vigor el 20 de marzo de 1992, el delito se castigaba con cadena perpetua. 
cesaria en una sociedad democrática. El Tribunal vuelve a remitirse a la decisión de la Comisión en el asunto B.H., M.W., H.P. y G.K. contra Austria (1989). Y en relación con la sección 3a (2) de la Ley, que es la norma aplicada en este caso al demandante, constata que prohíbe la creación y dirección de grupos que pretendan minar el orden público y la independencia de Austria a través de las actividades de sus integrantes inspiradas en las ideas nacional-socialistas. El demandante fue hallado culpable de ocupar una posición de liderazgo dentro de un grupo de esas características. Así las cosas, el Tribunal extrae una vez más del art. 17 del Convenio la conclusión de que la condena del demandante era necesaria en una sociedad democrática y, tras rechazar esta parte de la demanda por ser manifiestamente infundada, acaba declarando, por unanimidad, la inadmisibilidad de la demanda.

\section{DEMANDAS CONTRA FRANCIA}

En Francia, la polémica ley Gayssot, la Ley n. ${ }^{\circ}$ 90-615 de 13 de julio de 1990 tendente a reprimir los actos racistas, antisemitas y xenófobos, más conocida por el nombre del diputado comunista que la promovió, añadió un nuevo apartado al art. 24 de la vieja Ley de 1881, que ya sancionaba la apología de los crímenes contra la humanidad, creando un delito específico de negación del Holocausto ${ }^{16}$. Este precepto castiga con una pena de un mes a un año de prisión y multa la negación pública de la realidad o de la magnitud del genocidio de los judíos perpetrado por los nazis, identificando la verdad histórica con la verdad judicial establecida por el Tribunal de Nuremberg, puesto que alude expresamente a la definición de crímenes contra la humanidad contenida en art. 6 del Estatuto del Tribunal Militar Internacional anexo al Acuerdo de Londres de 8 de agosto de $1945^{17}$.

${ }^{16}$ En efecto, el art. 24-3 de la ley de 1881, modificada por ley de 31 de diciembre de 1987, castiga la apología de los crímenes contra la humanidad. Se define jurisprudencialmente como la publicación o apreciación pública que incita a quienes va dirigida a adoptar un juicio moral favorable sobre uno o varios crímenes contra la humanidad y tiende a justificar tales crímenes (incluido el de colaboración) o a sus autores. Por ejemplo, la publicación de un artículo en términos tales que incite al lector a adoptar un juicio favorable sobre los dirigentes nazis condenados como criminales de guerra y que constituya un intento de justificación. Los crímenes contra la humanidad son los definidos por el art. del Estatuto del Tribunal de Nuremberg (sólo los cometidos durante II Guerra Mundial). Se castiga con pena de prisión de uno a cinco años. En Francia coexisten pues los dos tipos penales: negación y apología del genocidio.

17 En lengua francesa original no se utiliza el término «negation», sino el de «contestation», tal vez algo más amplio: negar, impugnar, discutir, cuestionar, lo que podría comprender si así lo avala la jurisprudencia, la negación parcial o matizada o la puesta en tela de juicio. 
Como cabía esperar, la Comisión Europea de Derechos Humanos mantuvo el criterio que venimos exponiendo sobre la propaganda negacionista en la decisión de inadmisibilidad dictada el 24 de junio de 1996 en el caso Marais contra Francia. El demandante, Pierre Marais, ingeniero jubilado, publicó en un número de la revista periódica «Revisión» un artículo de tres páginas titulado «La cámara de gas homicida de Struthof-Natzweiler, un caso particular» ${ }^{18}$.

En enero de 1993, el procurador de la República de Paris citó al demandante a una comparecencia ante la $17^{\text {a }}$ sala correccional del Tribunal de Grande Instance de Paris por complicidad en la negación de un crimen contra la humanidad, hecho previsto y castigado por el art. 24 bis de la Ley sobre la prensa de 1881. El director de la revista fue también citado, por la publicación de ese y otros artículos, por provocación a la discriminación racial, apología de crímenes de guerra, difamación e injurias públicas raciales, y negación de crímenes contra la humanidad.

Mediante sentencia de 10 de junio de 1993, el tribunal correccional de Paris condenó al demandante a 10.000 francos de multa así como a pagar una cantidad en concepto de daños y perjuicios a las asociaciones que se habían constituido en partes civiles. El tribunal consideró que el art. 24 bis no era incompatible con el art. 10 del CEDH porque tal precepto, introducido en 1990, «se inscribe en el marco de la lucha contra el racismo y responde a los compromisos internacionales de Francia». Este artículo somete el ejercicio de la libertad de expresión a restricciones que constituyen medidas necesarias, en una sociedad democrática, para la protección de la reputación o los derechos de los demás, así como la seguridad pública, en el sentido del art. 10.2 del Convenio. Las expresiones que niegan la existencia de crímenes contra la humanidad «atentan con-

${ }^{18}$ Este artículo, que se refería al campo de concentración de Struhhof, concluía así: «El presente estudio no pretende el rigor científico. Trata de paliar justamente la ausencia de un trabajo más profundo que los especialistas habrían debido abordar para verificar los diarios del antiguo comandante del campo Josef Kramer. El autor se ha esforzado pues por colmar una laguna de la historia de la deportación utilizando un razonamiento provocador, justamente para suscitar réplicas que contribuyan a establecer la verdad sobre los pretendidos gaseamientos de Struthof-Natzweiler. Si el principio químico de base es correcto, este estudio revela que su aplicación para producir la asfixia rápida y simultánea de treinta personas no es verosímil dada la enorme cantidad de agua que habría sido necesaria para realizar tal operación. La comparación con el procedimiento de gaseado empleado en Estados Unidos para ejecutar a un solo condenado pone de relieve el carácter "artesanal « del método supuestamente utilizado por Kramer, cuando los alemanes no podían ignorar la reacción ácido sulfúrica-sal cianhídrica y disponían además... de grandes cantidades de Zyklon B, insectida con el que habrían ejecutado, se dice, a millones de personas en otros campos de concentración y que podían haber utilizado también en Struthof. Los supuestos gaseamientos de Struthof parece que constituyen en efecto un caso particular». 
tra la memoria de las víctimas del nazismo y son susceptibles de ocasionar disturbios por la propagación de ideas que tienden a rehabilitar la doctrina y la política de discriminación racial nazi».

En cuanto al fondo, el tribunal estimó que pese al título del artículo, la demostración y sus conclusiones se apoyan en la «confesión» del jefe del campo de Struthof como mero pretexto y tienden a afirmar, de una manera más general, la inverosimilitud técnica de las "presuntas cámaras de gas», cuya existencia fue sin embargo desvelada en la decisión de 1 de octubre de 1946 del Tribunal militar internacional de Nuremberg, en el capítulo titulado «Persecución de los judíos».

El demandante apeló esa decisión. Y el Tribunal de Apelación de Paris, en su sentencia de 2 de diciembre de 1993, rechazó el recurso, advirtiendo, entre otras cosas, que no era juez de la Constitución y la definición legal de una infracción se imponía a los jueces en el marco de la separación de poderes. La sentencia confirmó la condena poniendo de relieve que "el autor del artículo daba a entender que él negaba la realidad del exterminio de la comunidad judía por el régimen nazi y la utilización a esos efectos de las cámaras de gas mediante el empleo de una formulación muy dubitativa». La Cour de Cassation rechazó igualmente el recurso interpuesto por el demandante mediante sentencia de 7 de noviembre de 1995, con un argumento similar: para declarar al imputado culpable, los jueces han considerado que el autor del artículo no se ha limitado a poner en duda «los supuestos gaseamientos» efectuados en el campo de Struthof en agosto de 1943 sino también la utilización de cámaras de gas en otros campos de concentración con el fin de exterminar a la comunidad judía.

En su escrito de demanda ante el TEDH, además de invocar la supuesta violación del art. 6 del Convenio y denunciar la «caza de brujas» de la que ha sido víctima, el demandante sostiene que no hay ninguna posibilidad de limitar en este caso la libertad de expresión, que encierra aquí lo que tiene de más noble, la expresión del espíritu de investigación («l'esprit de recherche») en acción. Sin un debate libre, la razón quedaría sepultada bajo el fanatismo.

Para la Comisión, se trata de una injerencia prevista por la ley, que persigue finalidades legítimas: en este caso, «la defensa del orden y la prevención del delito» y «la protección de la reputación o los derechos de los demás». Queda por ver si responde a una "necesidad social imperiosa». La Comisión recuerda que, en contra de la afirmación del demandante según la cual el art. 10.2 del Convenio no se aplicaría a "la investigación científica», suponiendo que se trate en este caso de una publicación "científica», el apartado 2 del art. 10 no distingue en función de la naturaleza de la expresión.

La Comisión estima que las disposiciones pertinentes de la ley de 1881 y su aplicación en este caso tratan de preservar la paz en el seno de la población fran- 
cesa. Por tanto, la Comisión tiene también en cuenta el art. 17 del Convenio. Y toma nota de los hechos constatados por los tribunales internos en cuanto al contenido de la publicación, mediante la cual el demandante pretendía en realidad, bajo la apariencia de una demostración técnica, poner en cuestión la existencia y la utilización de cámaras de gas para el exterminio humano en masa.

Considera la Comisión que los escritos del demandante van en contra de los valores fundamentales del Convenio, tal y como se formulan en su preámbulo, a saber, la justicia y la paz. El demandante intenta desviar el art. 10 de su auténtica vocación o razón de ser, utilizando su derecho a la libertad de expresión con fines contrarios a la letra y al espíritu del Convenio que, de ser admitidos, contribuirían a la destrucción de los derechos y libertades garantizados por el Convenio.

En consecuencia, los motivos invocados para condenar al demandante eran pertinentes y suficientes y la injerencia era necesaria en una sociedad democrática en el sentido del art. 10.2 del Convenio. Se rechaza pues la demanda como manifiestamente mal fundada tanto en lo relativo al art. 10 como en lo que concierne a la alegada infracción del art. 6, por lo que la Comisión, esta vez por mayoría, la declara inadmisible.

Pero seguramente el pronunciamiento más relevante en esta materia sea la decisión de inadmisibilidad dictada el 24 de junio de 2003 por la cuarta sección del Tribunal Europeo de Derechos Humanos en el asunto Garaudy contra Francia.

El demandante, Roger Garaudy, es un conocido escritor y filósofo francés, autor de numerosos libros y ensayos relativos a la historia, la filosofía, el marxismo, la religión y el diálogo de civilizaciones. Hombre político, humanista marxista y después católico, se convirtió finalmente al Islam. En diciembre de 1995, Garaudy publicó una obra titulada "Los mitos fundadores de la política israelin, que fue publicada y distribuida fuera de los circuitos comerciales en 1995 y un año después editada por el propio autor. Diversas asociaciones de resistentes, de deportados y de defensa de los derechos humanos presentaron contra él demandas como presunto autor de los delitos de negación de crímenes contra la humanidad, difamación pública racial y provocación al odio racial. Estas demandas denunciaban el contenido de varios pasajes de la obra (que incluía capítulos dedicados al «mito del holocausto» o al «mito de la justicia de $\mathrm{Nu}$ remberg») y dieron lugar a la apertura de cinco procedimientos judiciales contra el demandante, todos ellos basados el la ley sobre la libertad de prensa de 1881 .

Mediante cinco sentencias fechadas el 16 de diciembre de 1998, el Tribunal de Apelación de Paris confirmó las condenas impuestas en primera instancia y declaró a Garaudy culpable de los delitos negación de crímenes contra la hu- 
manidad, difamación pública contra un grupo de personas, en este caso, la comunidad judía, y provocación a la discriminación y el odio raciales. El Tribunal estimó que las manifestaciones de Garaudy eran de carácter negacionista, que concurrían todos los elementos constitutivos del tipo penal y le condenó a penas de prisión de seis meses y a multas penales de 50.000 francos.

Para el Tribunal de Apelación no hay duda de que el propósito de la obra es negar la existencia de una «solución final» organizada para exterminar sistemáticamente a los judíos. La refutación se extiende igualmente al modo en que se hizo, esto es, el asesinato en las cámaras de gas y la posterior incineración de los cuerpos de quienes ya no estaban en condiciones de trabajar ${ }^{19}$. Garaudy banaliza un acontecimiento excepcional como es el de la eliminación de personas en razón de su pertenencia a una raza, al comparar ese horrendo crimen con actos que reprocha a los aliados y otras situaciones históricas ${ }^{20}$. Se muestra escéptico también sobre la existencia de un vasto "pogrom» contra los judíos. En su opinión, se trató simplemente de una expulsión en dirección al Este. Y subraya la necesidad de un debate público y científico entre especialistas sobre ciertos informes y documentos que ponen en duda el exterminio masivo. El mito de los seis millones de judíos exterminados se ha disfrazado de historia y se utiliza políticamente. Se ha convertido en un dogma sagrado que justifica todas las exacciones.

Según el Tribunal, Garaudy niega la solución final (o al menos que ésta significase el exterminio; lo que se organizó fue en realidad una operación de expulsión y exilio fuera de Europa), cuestiona el número de víctimas judías y la causa de su muerte, que atribuye a las deportaciones, el trabajo forzoso al servicio de la máquina de guerra alemana y las epidemias. La política de exterminio es inverosímil, surrealista, porque Hitler necesitaba mano de obra para sus fábricas y no tenía sentido eliminar a quienes podría trabajar, aunque fuese en condiciones inhumanas. Ante el Tribunal, Garaudy insistió en que no existen

19 Garaudy habla del «espectro» de las cámaras de gas o de la existencia de hornos crematorios en todas las grandes ciudades, sin que esas incineraciones respondan a una voluntad de exterminio de la población. No da pues ninguna relevancia o significado especial a su presencia en los campos de concentración. Y se permite el escarnio de utilizar expresiones como «Shoah business".

${ }^{20}$ Lamenta que ni Churchill, ni Stalin ni Truman se sentasen en el banquillo de los criminales de guerra cuando fueron los autores de los más innobles llamamientos al crimen y al genocidio. Entre los acusados de Nuremberg no figuraban los responsables anglo-americanos del bombardeo de Dresde ni el responsable del apocalipsis atómico de Hiroshima y Nagasaki. De ahí su descalificación de este Tribunal como tribunal ilegítimo impuesto por los vencedores que sólo se ocupó de los crímenes de los vencidos. 
pruebas de que la solución final fuese el exterminio de los judíos y tampoco de la existencia de cámaras de gas en Auschwitz. Todo este conjunto de elementos ponían en evidencia que Garaudy había cometido el delito que se le imputaba.

Garaudy recurrió, alegando que su condena en aplicación del art. 24 bis del Código Penal no encajaba en ninguna de las excepciones autorizadas por el art. 10.2 del CEDH al tratarse de una obra política que no era racista ni negaba los crímenes nazis. Pero la Cour de Cassation confirmó esas condenas mediante cinco sentencias de 12 de septiembre de 2000, fundiendo en una sola las cinco penas de prisión e incrementando la cuantía de las multas y el montante de las indemnizaciones concedidas a las partes civiles en concepto de daños y perjuicios. Una agravación que se justifica por la especial gravedad de los hechos imputados al recurrente, puesto que se trata en realidad de «un trabajo de deconstrucción de los valores sobre los que se basa la lucha contra el racismo y muy particularmente contra el antisemitismo", en el que el autor trata de desacreditar a la comunidad judía en su conjunto, generando en su contra un sentimiento de hostilidad, y atenta de modo flagrante contra los valores universales de nuestra civilización.

El Tribunal afirma que las sentencias recurridas habían apreciado correctamente el sentido y el alcance de palabras litigiosas, a la vista de los términos empleados en numerosos pasajes y también de otros elementos contenidos en otras partes de la obra. La negación de los crímenes contra la humanidad entra dentro de las previsiones del art. 24 bis aun cuando se presente de forma solapada o dubitativa o incluso mediante la insinuación; y se disfrace de búsqueda de una supuesta verdad histórica.

Garaudy denuncia en su demanda ante el TEDH, presentada en octubre de 2000, la violación, entre otros, de su derecho a la libertad de expresión. A su juicio, el art. 24 bis de la ley de 1881, que sirvió de base a tres de los cinco procedimientos dirigidos contra él, atenta contra el art. 14 del Convenio, en la medida en que instituye un delito político con el fin de proteger a las víctimas de religión judía, excluyendo a las demás víctimas ${ }^{21}$, y sobre todo contra los arts. 9 y 10 de ese mismo texto, porque no constituye una medida necesaria en una sociedad democrática, en el sentido del art. 10.2 CEDH. Al castigar a quienes cuestionan la existencia de crímenes contra la humanidad, tiende a hacer im-

${ }^{21}$ Garaudy denuncia el trato preferencial que la ley y los tribunales reservan al pueblo judío, en detrimento de otros grupos igualmente perseguidos (como gitanos $\mathrm{u}$ homosexuales, pero también armenios o tutsis). Al haberle condenado por recordar otras persecuciones, los tribunales franceses han considerado el genocidio judío como un crimen excepcional. Ahí estaría precisamente el origen de la diferencia de trato discriminatoria entre judíos y no judíos. 
posible todo debate histórico sobre esos crímenes y a imponer una única versión de la verdad histórica que no se puede poner en tela de juicio, so pena de verse condenado por revisionista. El art. 24 bis crearía así un delito que interfiere en la libre investigación histórica y la expresión de opiniones polémicas que merecen ser debatidas. Se trata pues de un mecanismo de censura que restringe de forma abusiva la libertad de expresión, que criminaliza opiniones. En suma, ha sido condenado en virtud de una ley que resulta a todas luces incompatible con los arts. 9 y 10 del Convenio.

Se queja, por otra parte, de que los tribunales franceses no captaron correctamente el sentido de sus escritos. El nunca ha negado en su obra la existencia de los crímenes nazi contra el pueblo judío ni su calificación como crímenes contra la humanidad. El libro en cuestión se inscribe en el marco del estudio de las tres grandes religiones monoteístas. Después de haber examinado el integrismo católico y el islamista, quiso reflexionar sobre sionismo político, otra forma de integrismo. Sin pretender ser un historiador, quiso escribir una obra política, destinada a combatir el sionismo y a criticar la política colonialista del Estado de Israel y no la fe judía. En ausencia de cualquier atisbo de pensamiento racista o antisemita, Garaudy alegaba que no podía ser considerado como un negacionista y en consecuencia se debería haber beneficiado sin restricción alguna de la libertad de expresión.

El demandante estima, en efecto, que su conducta no presentaba las características típicas del delito que se le imputó. En lo que concierne al elemento de banalización de los hechos, el demandante sostiene que, como otros autores, no hizo otra cosa que comparar las persecuciones sufridas por los judíos con las padecidas por otros pueblos. Su única pretensión era afirmar el derecho de todos los pueblos a no ser perseguidos y a ser tratados en pie de igualdad, así como desmitificar el sionismo. Por lo que respecta a la descalificación de las instituciones, alega que se limitó a analizar de una forma crítica el acuerdo de Londres, el estatuto del Tribunal militar internacional y el proceso de Auschwitz y que lejos de un enfoque negacionista quiso combatir la propaganda que limita la memoria histórica a una sola categoría de víctimas (un fenómeno que él denomina «el apartheid de los muertos»). En cuanto a su visión sobre la naturaleza de la solución final, el demandante explica que, por rotundo que fuese en este punto el pronunciamiento del Tribunal de Nuremberg, el significado exacto del término y la existencia o no de una decisión de ejecutarla han sido siempre objeto de discusión entre los historiadores. Considera que tiene el derecho a expresar libremente su opinión sobre este asunto. En relación con el número de víctimas y la causa de su muerte, Garaudy mantiene que la cifra de seis millones de muertos judíos durante la Segunda Guerra Mundial ha sido exagerada para justificar 
la caracterización de los crímenes nazis como el mayor genocidio de la historia de la humanidad en detrimento de otras víctimas, como los eslavos, los homosexuales o los gitanos. Pero el horror de este genocidio no reside en las cifras sino en el injusto sufrimiento de las víctimas (cualquiera que sea su número). Finalmente alude el demandante a su postura en relación con la existencia de las cámaras de gas. Dice que se limitó a citar documentos que le parecieron serios y esas citas no pueden considerarse un acto negacionista.

El Gobierno rechazó la tesis del demandante e invitó al Tribunal a considerar la demanda inadmisible en aplicación del art. 17 del Convenio, o del art. 10.2 a la luz del art. 17. Se funda para ello en la jurisprudencia de la Comisión y del propio Tribunal. En su opinión, cuando el derecho a la libertad de expresión ha sido invocado por los demandantes para justificar la publicación de textos que atentaban contra el espíritu mismo del Convenio y los valores esenciales de la democracia, la Comisión ha recurrido siempre al art. 17 del Convenio para rechazar sus argumentos y declarar inadmisibles las demandas, un enfoque que confirmaría después el Tribunal. Aplicando esa doctrina a este caso, el Gobierno cree que el verdadero objetivo de los escritos del demandante era poner en duda la realidad del holocausto, para lo cual hizo suyas las tesis negacionistas.

El Tribunal comienza advirtiendo que no va a pronunciarse sobre los elementos constitutivos de los delitos de negación de los crímenes contra la humanidad, de difamación pública racial o de provocación al odio racial en el Derecho francés. Incumbe en primer lugar a las autoridades nacionales, y en particular a los tribunales, interpretar y aplicar el Derecho nacional. El Tribunal tiene como misión únicamente verificar bajo el ángulo del art. 10 las decisiones adoptadas por los tribunales nacionales competentes. Al hacerlo, ha de convencerse de que las autoridades nacionales se fundaron en una apreciación aceptable de los hechos pertinentes.

En lo que concierne a la condena por la negación de crímenes contra la humanidad, la sentencia del Tribunal se refiere en primer lugar al art. 17 del Convenio, que tiene por objetivo impedir que, al amparo del mismo, alguien pueda arrogarse el derecho a desarrollar actividades o realizar actos tendentes a destruir los derechos y libertades reconocidos en el propio Convenio. Nadie puede prevalerse del Convenio para realizar actos contrarios a sus disposiciones.

La obra que está en el origen de las condenas impuestas al demandante analiza de forma detallada diversos acontecimientos históricos durante el período de la Segunda Guerra Mundial: «apoyándose en numerosas citas y referencias, el demandante pone en cuestión la realidad, la amplitud y la gravedad de hechos históricos que no son objeto de debate entre los historiadores sino que por el contrario están claramente establecidos». Parece que, como han demostrado los tri- 
bunales nacionales tras un estudio metódico y profundo, lejos de limitarse a una crítica política o ideológica del sionismo o de las actuaciones del Estado de Israel, o incluso de proceder a una exposición objetiva de las tesis negacionistas y de reclamar un debate público y científico sobre las cámaras de gas, el demandante hizo suyas las tesis negacionistas y puso en cuestión sistemáticamente los crímenes contra la humanidad cometidos por los nazis contra la comunidad judía.

Según el Tribunal, no hay duda de que negar la realidad de hechos históricos claramente establecidos, como el Holocausto, no constituye un trabajo de investigación histórica que guarde relación con una búsqueda de la verdad. En realidad, un enfoque de ese tipo tiene como objetivo rehabilitar el régimen nacional-socialista y por ende acusar de falsificación de la historia a las propias víctimas. La negación de crímenes contra la humanidad se presenta pues como una de las formas más agudas de difamación racial contra los judíos y de incitación al odio contra ellos. La negación o la revisión de hechos históricos de ese tipo ponen en cuestión los valores sobre los que se funda la lucha contra el racismo y el antisemitismo y dada su naturaleza pueden perturbar gravemente el orden público ${ }^{22}$. Tales actos son incompatibles con la democracia y los derechos humanos y sus autores buscan sin duda objetivos que el art. 17 prohíbe. Para el Tribunal, la obra del demandante tiene, en su conjunto, un marcado carácter negacionista, y va en contra de los valores fundamentales del Convenio, a saber, la justicia y la paz. Llega por tanto a la conclusión de que el demandante intentó desviar el art. 10 del Convenio de su auténtica vocación (alterando su sentido o razón de ser) utilizando su derecho a la libertad de expresión para fines contrarios al mismo. En consecuencia, el Tribunal declara la demanda incompatible con el Convenio ${ }^{23}$.

22 Véase, en ese mismo sentido, la decisión del Comité de Derechos Humanos de la ONU, fechada el 16 de diciembre de 1996, en el asunto Robert Faurisson contra Francia.

${ }^{23}$ En cuanto a los pasajes del libro de Garaudy en los que se critica la política del Estado de Israel que están en el origen de las condenas por difamación racial y provocación al odio racial, el Tribunal considera que constituyen injerencias en su derecho a la libertad de expresión, previstas en la ley (en este caso en la de 29 de julio de 1881) y con finalidades legítimas. Sin embargo, admite que alberga serias dudas acerca de si, por las mismas razones que las indicadas anteriormente, y teniendo en cuenta el tono global negacionista de la obra, las expresiones que han motivado esta condena estarían protegidas por el art. 10. Porque el demandante no se limita a formular esa crítica sino que sus afirmaciones tienen un claro objetivo racista. Pero no considera necesario pronunciarse sobre este punto, porque la motivación de los tribunales nacionales que condenaron al demandante era pertinente y suficiente y las injerencias en el derecho a la libertad de expresión del afectado eran "necesarias en una sociedad democrática», con arreglo al art. 10.2 del Convenio. Por esa razón, el Tribunal estimó que esta queja estaba también mal fundada, y mediante una decisión unánime, declaró inadmisible la demanda. 
La postura mantenida en los asuntos relacionados con la negación del Holocausto contrasta llamativamente con la que adoptó el Tribunal Europeo en el asunto Lehidoux e Isorni contra Francia, que guardaba también relación con la memoria histórica, pero de otros acontecimientos. La sentencia dictada el 23 de septiembre de 1998 puso punto final a un caso muy controvertido dentro incluso del propio TEDH (de hecho se formularon varios votos particulares disidentes). Los demandantes, colaboradores en su día del mariscal Petain (como secretario de Estado y abogado defensor, respectivamente) denuncian la sanción penal (un franco por los daños ocasionados y la publicación de la sentencia condenatoria) que les impuso el Tribunal de Apelación de Paris en 1990 (decisión confirmada en 1993 por la Corte de Casación) por apología de crímenes o delitos de colaboración (conducta castigada en la ley de prensa de 1881) a raíz de la publicación en el periódico Le Monde de un anuncio publicitario contratado por dos asociaciones legalmente constituidas cuya finalidad es promover la rehabilitación de Petain, glorificando ciertos aspectos de la vida pública del antiguo Jefe del Estado francés, que fuera condenado a muerte tras la liberación en 1945. Consideran que con su condena se trata de imponer una visión políticamente correcta de la historia, cuando éste es un ámbito en el que la controversia es saludable. Admiten la posible existencia de omisiones, pero no puede asimilarse su texto con la literatura revisionista o negacionista. Porque, entre otras cosas, no niegan la barbarie nazi.

Aunque efectivamente el texto, titulado "Franceses, tenéis la memoria corta», ponía de relieve las «atrocidades» y las "persecuciones nazis», se elogiaba sin reservas la figura de Petain y su habilidad política (en particular, su papel en la entrevista con Hitler en 1940) para frenar la omnipotencia alemana y su barbarie y preparar y contribuir a la liberación de Francia. Recordaba las principales etapas de la trayectoria pública de Petain desde 1916 a 1945, presentándose todas sus acciones como positivas.

La condena tuvo su origen en una acción promovida por la Asociación Nacional de antiguos combatientes de la Resistencia, contra los dos demandantes y el director del diario, al entender que anuncio constituía una apología penalmente punible, puesto que trataba de justificar la acción política de Petain.

El Tribunal procura mantenerse equidistante respecto de las dos tesis en presencia, la del «doble juego» de Petain, apuntada por los demandantes, y la del Gobierno francés, que considera manifiestamente errónea la forma en que se presentan determinados acontecimientos históricos, ocultándose además otros hechos esenciales, que califica de notorios e incontrovertibles. Para la representación del Estado demandado, el texto no respondería a las exigencias de una mínima objetividad, ya que la política del doble juego ha sido refutada por todos 
los especialistas. Considera el TEDH que no le corresponde arbitrar en esta cuestión, que es objeto de una largo debate entre los historiadores, y que «escapa a la categoría de los hechos históricos claramente establecidos, como el Holocausto, cuya negación o revisión quedaría sustraída por el artículo 17 a la protección del art. $10 »$.

$\mathrm{Al}$ analizar el contenido de la publicación, admite que es polémica y unilateral (totalmente favorable a Petain), y examina a continuación los argumentos esgrimidos por los tribunales franceses (a Petain se le reprocha, en particular, la firma de la ley de octubre de 1940 relativa a los judíos). No tiene reparo en aceptar que "la justificación de una política pronazi no podría beneficiarse de la protección del art. 10», pero añade que los demandantes se habían desmarcado de esa política, haciendo más un elogio del hombre, cuya rehabilitación pretenden, que de su política. Reconoce el Tribunal el silencio de los autores del texto (moralmente condenable) sobre las graves responsabilidades por haber colaborado con el régimen nazi en la persecución y deportación de miles de judíos de Francia (los tribunales franceses habían subrayado la ausencia de toda crítica en relación con unos hechos hábilmente silenciados), y que la gravedad de los hechos, la participación en un crimen contra la humanidad, aumenta la gravedad de cualquier intento de ocultarlo, pero el transcurso del tiempo permite dudar de la necesidad, 40 años después, de aplicar la misma severidad que diez o veinte años antes. El Tribunal apela al esfuerzo que todo el país está llamado a hacer para debatir abiertamente y serenamente acerca de su propia historia. La mayoría de los jueces llega a la conclusión de que la injerencia no era necesaria y supuso una violación del art. $10 \mathrm{CEDH}$.

Criticaron en su momento esta decisión quienes pensaban que la publicación no podía considerarse una contribución a ese debate histórico, dado su carácter parcial y publicitario (en esta dirección apunta una de las opiniones disidentes). Otro argumento utilizado por los críticos, que no carece de fundamento, es que la sentencia desconoce el amplio margen de apreciación otorgado habitualmente a los Estados cuando se trata de emitir un juicio sobre la presentación de la historia de un país y sobre el efecto de una publicación sobre los sentimientos de un sector importante de la población. En esa línea se inscribe la opinión del juez español Morenilla, que coincide con la tesis del Gobierno francés: es una página particularmente sombría y dolorosa de la historia de Francia que estaba muy viva aún en la memoria colectiva en 1984, debido a las dificultades para reconocer las posibles responsabilidades. Se trata pues de cuestión sensible, delicada, que escapa a cualquier definición uniforme a escala europea. Las autoridades nacionales estarían en mejores condiciones para apreciar sobre el terreno esas consecuencias. 
La conclusión que puede extraerse de esta sentencia es que el Tribunal parece inclinarse por un control de geometría variable, por una doble vara de medir: sobre holocausto ni una broma, no hay discusión posible, es un hecho incontestable; sobre el régimen colaboracionista de Vichy y el papel de Petain sí cabe, en cambio, el debate, y se admite incluso una cierta banalización (el Tribunal se declara neutral, porque no es un hecho claramente establecido, salvo en lo relativo a la persecución de los judíos).

Precisamente en relación con un conocido episodio de la lucha de la Resistencia francesa contra el ocupante alemán, los ciudadanos franceses Gérard Chauvy y Francis Esmenard y la editorial Albin Michel ${ }^{24}$ que habían sido condenados como responsables de la difusión de un libro que cuestionaba hechos históricos hasta entonces indiscutidos, presentaron en el año 2000 una demanda ante el Tribunal de Estrasburgo (Chauvy y otros contra Francia) que fue desestimada mediante sentencia dictada el 29 junio 2004.

En su libro, Chauvy describía la cronología de los acontecimientos acaecidos en Lyón en 1943. Una de las principales zonas de sombra de este período es la reunión de Caluire, particularmente importante para la historia de la Resistencia francesa. En efecto, el 21 de junio de 1943, Klaus Barbie, jefe regional de la Gestapo, arrestó a los principales jefes de la Resistencia reunidos en las afueras de Lyón, en Caluire. En ese momento fueron arrestados, entre otros, Jean Moulin, delegado del general De Gaulle en Francia y jefe de la Resistencia interior, y Raymond Aubrac, miembro de la Resistencia, que consiguió evadirse en otoño de 1943. Otro miembro de la Resistencia, René Hardy, hoy fallecido, fue acusado y juzgado por ser el «traidor», pero tras dos procesos diferentes, no fue condenado.

El libro, que provocó una encendida polémica en Francia, analizaba este acontecimiento capital bajo el prisma del matrimonio Aubrac y ponía a prueba la «verdad oficial contada durante mucho tiempo por el matrimonio Aubrac en los medios de comunicación, y contada también en una película para gloria suya». El informe firmado por Klaus Barbie y entregado en 1990 por su abogado al Juez que instruía el procedimiento seguido contra él por su papel en la represión de los miembros de la Resistencia de Lyón, fue incluido en su totalidad en el libro en cuestión. Chauvy reconoce que ningún documento de los archivos permite validar la acusación de traición proferida por Klaus Barbie contra Raymond Aubrac, pero expone una serie de interrogantes que ponen en duda la inocencia del Raymond Aubrac.

${ }^{24}$ Gérard Chauvy, periodista y escritor, era el autor del libro titulado AUBRAC-Lyón 1943 publicado en 1997 por Éditions Albin Michel, cuyo presidente era a la sazón Francis Esmenard. 
Nada más publicarse el libro, el matrimonio Aubrac inició un procedimiento judicial ante la Sala 17a del Tribunal de Gran Instancia de París. La citación incluía cincuenta pasajes extraídos de la obra litigiosa. La acción iba dirigida contra los tres demandantes como autor, cómplice y civilmente responsable del delito de difamación.

Mediante sentencia de 2 de abril de 1998, el Tribunal procedió, en primer lugar, al examen de las diferentes acusaciones supuestamente difamatorias y concluyó que el demandante, sin corroborar formalmente las acusaciones sacadas del «informe Barbie», se dedicó a sembrar la confusión a partir de una serie de hechos, testimonios y documentos, de diferente naturaleza e importancia, que de manera subrepticia vienen a dar crédito - pese a las reservas que plantea el autor- a la acusación de traición y de manipulación incluida en el «informe Barbie». El matrimonio Aubrac tenía motivos para considerar que la obra atentaba contra su honor.

Además, las imputaciones difamatorias se suponían hechas de mala fe y eran los presuntos responsables de la infracción los que debían presentar hechos justificativos suficientes que probaran su buena fe. Debían establecer que su actitud respondía a un interés legítimo, que no iba acompañada de una animosidad personal, que se había realizado una investigación seria y que las conclusiones estaban formuladas de manera mesurada ${ }^{25}$. En este caso, la publicación del demandante se caracterizaba por conceder una importancia excesiva al Informe Barbie, una insuficiencia manifiesta de la documentación relativa a las circunstancias del primer arresto del Raymond Aubrac el 15 de marzo de 1943 y a su puesta en libertad, y una utilización incorrecta e imprudente de las fuentes.

Los hombres y mujeres que lucharon heroicamente en la Resistencia, convertidos por sus contemporáneos en mitos ilustres, no son simples objetos de estudio, despojados de su personalidad y privados de sensibilidad. Por haber olvidado eso, por haber perdido de vista la responsabilidad social del historiador, y por haber faltado a las reglas esenciales del método histórico, no se puede conceder al procesado (el autor de la obra) el beneficio de la buena fe. El Tribunal declaró a los dos primeros demandantes culpables del delito de difamación pública contra el matrimonio Aubrac, en su condición de miembros de un movi-

${ }^{25}$ El trabajo del historiador, que debe poder ejercerse con plena libertad, puede llevarle en algunos casos a formular apreciaciones críticas que supongan imputaciones difamatorias contra actores vivos o muertos de los acontecimientos que estudia, pero en estos casos tiene que aportar la prueba de su fidelidad al método científico. El Tribunal admite que la publicación íntegra del «informe Barbie» es útil, pero tendría que haber ido acompañada de un trabajo crítico que pudiera permitir al lector forjarse una opinión seria sobre el valor que había que conceder a las últimas declaraciones del antiguo oficial nazi. 
miento reconocido de la Resistencia, delito previsto y castigado por los artículos 29 y 31 de la Ley de 29 de julio de $1881^{26}$.

Agotados los remedios internos ${ }^{27}$, los condenados presentaron la correspondiente demanda ante el TEDH alegando la violación de su derecho a la libertad de expresión. Para el Tribunal, la medida constituía una injerencia prevista por la ley que respondía a una finalidad legítima ${ }^{28}$. En cuanto a la necesidad de la injerencia en una sociedad democrática, los demandantes insisten en el carácter histórico del libro y en el derecho del público a conocer su propia historia. Y denuncian la actitud de los tribunales internos, que consagran el papel intervencionista del Juez en materia histórica y su derecho a controlar cualquier trabajo de investigación histórica, negando el derecho a debatir la historia oficial comúnmente admitida en Francia y privándoles de su libertad de expresión en materia histórica. Los tribunales franceses no permiten que se cuestione el papel del matrimonio Aubrac como héroes de la Resistencia, negando a los historiadores la posibilidad de interrogarse sobre su comportamiento. Para los demandantes, ninguna necesidad social imperiosa justificaba sustraer este acontecimiento de la libertad de opinión del historiador.

Por lo demás, el autor del libro se basaba en fuentes auténticas y confirmadas, que fueron objeto de una lectura crítica. En sus páginas se ponían sistemáticamente en duda las acusaciones hechas por Klaus Barbie. Y se utilizaron los testimonios de dos miembros de la Resistencia, testigos directos de los hechos objeto de la investigación. Los demandantes subrayan, finalmente, el tono prudente del libro.

El Gobierno, por su parte, sostiene que los tribunales internos sopesaron correctamente los diversos intereses en juego y examinaron minuciosamente el fun-

${ }^{26}$ El TGI de Paris condenó al primer demandante, como autor principal, a una pena de 100.000 francos de multa y al segundo, como cómplice, a 60.000 francos de multa. Les condenó también solidariamente a pagar al matrimonio Aubrac una indemnización (2.000.000 francos a cada uno de ellos). El Tribunal rechazó la solicitud de destrucción del libro, pero ordenó la publicación de un comunicado en cinco periódicos y la inserción en cada ejemplar del libro de un aviso reproduciendo los términos de este comunicado. Declaró finalmente a la editorial civilmente responsable.

${ }^{27}$ Los demandantes recurrieron esta resolución ante el Tribunal de Apelación de París, que rechazó el recurso en su sentencia de 10 de febrero de 1999. Tampoco prosperó el recurso ante el Tribunal de Casación (sentencia de 27 de junio de 2000).

${ }^{28} \mathrm{El}$ Gobierno francés alegó que las resoluciones de los tribunales internos tenían por objeto proteger al matrimonio Aubrac contra la difamación, puesto que su reputación se había visto gravemente afectada por la velada acusación de traición. El Tribunal coincide con esa apreciación del Gobierno: las resoluciones judiciales tenían por objetivo «la protección de la reputación o de los derechos ajenos», uno de los fines legítimos enunciados en el segundo apartado del artículo 10 del Convenio. 
damento de las acusaciones dirigidas contra el matrimonio Aubrac. Lo que le reprocharon al autor es el lugar central concedido al informe de Klaus Barbie, una fuente poco fiable, para cuestionar la tesis del matrimonio Aubrac, sin tener en cuenta los documentos oficiales y sin que los testigos directos, aún vivos en el momento de la elaboración del libro, fuesen interrogados. En todo caso, las sanciones impuestas a los demandantes no pueden ser consideradas especialmente severas.

El Tribunal de Estrasburgo considera que la búsqueda de la verdad histórica forma parte integrante de la libertad de expresión y que no le compete arbitrar la cuestión histórica de fondo, que pertenece al ámbito de un debate siempre en curso entre historiadores. Por esa razón, sean cuales sean las dudas que puedan albergarse sobre el carácter probatorio o no del documento denominado «informe» o «testamento Barbie», la cuestión escapa a la categoría de hechos históricos claramente establecidos -como el Holocausto- cuya negación o revisión quedaría fuera del ámbito de protección del artículo 10 (sentencias Lehideux e Isorni contra Francia; y Garaudy contra Francia).

Sin embargo, el Tribunal debe poner en la balanza, por un lado, el interés público por conocer las circunstancias en las que Jean Moulin, principal jefe de la Resistencia interior en Francia, fue arrestado por los nazis el 21 de junio de 1943, y por otro, la necesaria protección de la reputación del matrimonio Aubrac, miembros destacados de la Resistencia. Porque, más de medio siglo después de los hechos, se podía atentar gravemente contra el honor y la consideración de los Aubrac con un libro que suscitaba dudas, aunque fuera por insinuación, sobre la posibilidad de que hubieran traicionado a Jean Moulin y provocado así su arresto y su muerte.

El Tribunal observa que en este caso los tribunales internos procedieron a un examen detallado y muy minucioso del libro en cuestión y cree que las condenas están basadas en motivos pertinentes y suficientes. Al Tribunal le parece convincente el razonamiento de los tribunales civiles que les llevó a afirmar que la obra en cuestión no respetaba las reglas esenciales del método histórico. Y no encuentra ningún motivo para no compartir el meticuloso análisis del asunto que llevaron a cabo los tribunales internos, ni para considerar que éstos habrían interpretado de una forma demasiado restrictiva el principio de la libertad de expresión.

En cuanto a la gravedad de las penas impuestas, un elemento a tener en consideración cuando se trata de medir la proporcionalidad de la injerencia, la sentencia recuerda, en primer lugar, que no se ordenó la destrucción del libro y que no se prohibió su publicación. Y señala, en segundo lugar, que las multas e indemnizaciones parecen moderadas y están justificadas teniendo en cuenta las circunstancias del caso. 
En conclusión, el Tribunal considera unánimemente que la injerencia en la libertad de expresión de los demandantes no fue desproporcionada en relación con la finalidad legítima perseguida. Y no hubo por tanto violación del artículo 10 del Convenio.

En este tipo de litigios, no resulta fácil deslindar lo que es la expresión de una opinión de lo que es una afirmación fáctica. Si nos decantamos por la calificación de una determinada declaración como una información sobre hechos, se nos plantea un segundo problema, el de su veracidad o falsedad, una cuestión sujeta a menudo a controversia, sobre todo cuando se trata de hechos históricos complejos. Ya hemos aludido a las dificultades que encuentran los historiadores a la hora de verificar de forma fehaciente lo que ocurrió en el pasado, a la vista de las versiones parciales y selectivas que de un mismo acontecimiento pueden dar diferentes testigos e investigadores. ¿Cuándo podemos hablar de un hecho histórico establecido o incontestable? Hacer de la falsedad un criterio operativo que nos permite distinguir las expresiones protegidas de las que no lo están presupone que somos capaces de determinar con suficiente exactitud si una afirmación es o no objetivamente falsa. Una tarea que muchas veces resulta imposible o extremadamente difícil, porque un mismo enunciado puede tener distintos significados, unos falsos y otros en cambio válidos (como expresión metafórica, por ejemplo) y esos significados dependen no sólo de la perspectiva que se adopte sino también de quién sea el receptor, porque la comunicación es un proceso interactivo. Distintas personas pueden atribuir a una misma declaración significados diferentes en momentos diferentes.

En los procesos civiles por difamación, esta operación encierra también serias dificultades, pero pueden superarse normalmente recurriendo a la prueba directa. Aquí están en juego acontecimientos históricos del pasado que no se prestan a una demostración tan concluyente y que son objeto permanente de manipulación (no son pocos los intentos de reescribir la Historia).

En algunos ordenamientos se exige como ingrediente típico de la infracción penal un elemento que difícilmente puede acreditarse: el conocimiento por el acusado de la falsedad de sus afirmaciones. Esta exigencia obliga al juez a entrar en el terreno de las creencias subjetivas del acusado y a valorar su honestidad intelectual (si está sinceramente convencido o no de que lo que dice es cierto, refleja fielmente la realidad histórica). Un problema de naturaleza epistemológica, porque ¿cómo se puede probar más allá de toda duda el conocimiento por el acusado de la falsedad de su afirmación? Y no parece que la cuestión pueda despacharse diciendo que como todo el mundo sabe que es falso, el acusado tiene que saberlo. Como deducción lógica es, como mínimo, bastante discutible. ¿Es falso todo lo que no coincide con lo que habitual u oficialmente se tiene por verdadero, con las creencias dominantes? 
Con independencia de estas dificultades a la hora de averiguar si algo es falso o verdadero, lo que en el fondo se discute aquí es si la mentira deliberada y consciente constituye o no una forma legítima de expresión, constitucionalmente protegida. Quienes piensan que la libertad de expresión no protege jamás la difusión de mentiras, la grosera falsificación de los hechos, aducen que éstas no contribuyen a la verdad, ni favorecen la participación política. Para otros, no se puede concluir de forma categórica que esas mentiras carezcan siempre de todo valor. Una persona que lucha por una determinada causa puede citar conscientemente estadísticas falsas en su apoyo de sus tesis. Pensemos en una buena causa, en un médico que con el fin de persuadir a la gente de que debe vacunarse contra una epidemia, exagera el número de las personas que pueden verse afectadas. Todas estas formas de expresión tendrían un valor intrínseco, y representarían una contribución al debate público.

\section{UNA JURISPRUDENCIA EN SINTONÍA CON EL ENFOQUE DOMINANTE EN EUROPA}

En Europa, a diferencia de lo que sucede en los Estados Unidos, donde ha arraigado (y prevalece por el momento) una concepción liberal o libertaria incluso, la libertad de expresión se proclama, incluso en sede constitucional, como un derecho limitado, que ha de ejercerse responsablemente, dentro de ciertos márgenes, sin incurrir en abusos. En caso de conflicto, otros derechos y principios constitucionales pueden llegar a pesar tanto o más que la libertad de expresión. Es más, ha tenido siempre un fuerte arraigo la tendencia a amparar sólo las expresiones que cumplen una función saludable (la búsqueda de la verdad o la participación en el proceso democrático, por ejemplo) o que promueven determinados valores. Esta actitud de prevención, de cautela, ante las nefastas consecuencias de la libre difusión de ideas con un alto grado de toxicidad, de peligro para la convivencia no es fruto de la casualidad, no se produce por generación espontánea. Los traumas del pasado, de un pasado relativamente reciente aún, explican la especial sensibilidad de la mayoría de las sociedades europeas en este terreno. Es mejor prevenir que curar: la tolerancia con los intolerantes es una actitud suicida. Y es legítima, por tanto, la imposición de límites atendiendo al contenido del mensaje.

En el ámbito del Consejo de Europa, la Recomendación de Política General n. ${ }^{\circ} 7$ sobre legislación nacional para luchar contra el racismo y la discriminación racial aprobada por la Comisión Europea contra el Racismo y la Intolerancia el 13 de diciembre de 2002, recomendaba a los Estados miembros que sus legis- 
laciones calificasen como infracciones penales, entre otros comportamientos intencionales, "la negación, minimización grosera, justificación o apología públicas, con un objetivo racista, de delitos de genocidio, crímenes contra la humanidad o crímenes de guerra».

Y la Recomendación de Política General n. ${ }^{\circ} 9$ sobre la lucha contra el antisemitismo, aprobada el 25 de junio de 2004, hace una referencia expresa a la jurisprudencia del TEDH y recuerda que ésta «ha considerado que la negación de la existencia de crímenes contra la humanidad cometidos bajo el régimen nacional-socialista constituye una de las formas más graves de injuria racial y de incitación al odio a los judíos y que la refutación de tales crímenes contra la humanidad y la justificación de la política pro-nazi no pueden beneficiarse de la protección prevista por el art. 10 del $\mathrm{CEDH} »^{29}$.

La Comisión insta a los Estados a velar porque en la lucha contra el racismo, el Derecho penal tome en consideración el antisemitismo y penalice una serie de actos antisemitas, si son intencionales y, entre ellos, la expresión pública, con un objetivo antisemita, de una ideología que calumnie o denigre a un conjunto de personas en razón de su identidad o su origen judío; la negación, la minimización grosera, la justificación o la apología públicas de la Shoah; y la negación, la minimización grosera, la justificación o la apología públicas, con un objetivo antisemita, de los delitos de genocidio, los crímenes contra la humanidad o los crímenes de guerra cometidos contra personas en razón de su origen o su identidad judía

En el ámbito de la Unión Europea, y con el objetivo de armonizar la legislación de los Estados miembros en materia de delitos racistas y xenófobos y facilitar la cooperación entre Estados miembros para combatir estos delitos, la Comisión Europea presentó en noviembre de 2001 una Propuesta de Decisión-Marco del Consejo relativa a la lucha contra el racismo y la xenofobia. El propósito de esta Decisión marco es doble. Primero, asegurarse de que el racismo y la xenofobia son castigados en todos los Estados miembros mediante sanciones penales efectivas, proporcionadas y disuasorias, que pueden dar lugar a la extradición o entrega. Se trata de que la misma conducta racista y xenófoba sea punible en todos los Estados miembros, aunque éstos, son libres, por supuesto, para ir más lejos en ese proceso. Y en segundo lugar, mejorar y fomentar la cooperación judicial reduciendo los obstáculos potenciales que la dificultan.

${ }^{29}$ La Recomendación recuerda asimismo que la historia de Europa le confiere un deber de memoria, de vigilancia y de lucha contra todas las manifestaciones de racismo, xenofobia, antisemitismo e intolerancia y rinde homenaje a la memoria de las víctimas de la persecución sistemática y el exterminio de los judíos en la Shoah, así como la de otras víctimas de políticas de persecución y exterminio racistas durante la Segunda Guerra Mundial. 
En el documento se dice expresamente que se debe garantizar, en todo caso, el respeto de los derechos humanos y las libertades fundamentales, tales como la libertad de expresión y la libertad de reunión y asociación, garantizadas por los artículos 10 y 11 del CEDH. Se impone buscar un equilibrio entre el ejercicio de estas libertades y la prevención de desordenes o actos delictivos o la protección de la reputación o los derechos de los otros.

Pues bien, el artículo 4 (Delitos de carácter racista y xenófobo) de la Propuesta impone a los Estados miembros la obligación de tomar todas las medidas necesarias para que una serie de comportamientos racistas y xenófobos sean castigados por la ley como actos delictivos. Y entre las conductas que han de considerarse delictivas, se incluye dos que guardan relación con la cuestión que ahora nos ocupa:

(c) la apología pública con fines racistas o xenófobos de los crímenes de genocidio, crímenes contra la humanidad y crímenes de guerra tal como vienen definidos en los artículos 6, 7 y 8 del Estatuto del Tribunal penal internacional; y

(d) la negación pública o la banalización de los crímenes definidos en el artículo 6 del Estatuto del Tribunal Militar internacional adjunto al Acuerdo de Londres de 8 de abril de 1945 en la medida en que ello pueda perturbar el orden público. En relación con esta conducta, se hace notar en el documento que las modificaciones introducidas respecto del texto de la Acción común de 1996 están inspiradas en gran medida por el derecho alemán, que tipifica no sólo la negación, sino también la trivialización de los crímenes contemplados, cuando pueda suponer la perturbación del orden público.

En el marco del largo proceso de negociación y elaboración de esta Decisiónmarco, pendiente aún de aprobación definitiva, el pasado 19 de abril de 2007, en la reunión celebrada en Luxemburgo, los ministros de Justicia e Interior de los 27 Estados de la UE alcanzaron un acuerdo para que la incitación al racismo y la xenofobia sea un delito en todos ellos, aunque se introdujeron garantías respecto de aquellos Estados en los que la libertad de expresión permite ese tipo de manifestaciones. El acuerdo incluye las reservas provisionales de 7 países (Polonia, Eslovenia y algunos países bálticos), que necesitan la ratificación por sus Parlamentos o Gobiernos respectivos.

El acuerdo, impulsado por la presidencia alemana, establece penas de entre uno y tres años de prisión para la incitación al odio o la violencia contra grupos de personas y miembros concretos de esos grupos definidos por su ascendencia $\mathrm{u}$ origen étnico o nacional (raza, color, religión, nacionalidad u origen étnico), así como para la apología pública, la negación, la justificación o la banalización o trivialización de los crímenes de guerra o contra la humanidad o los genocidios 
reconocidos por el Tribunal de Nuremberg (alusión expresa que implica el reconocimiento del Holocausto como uno de esos crímenes) o por otros tribunales internacionales. El texto final obliga a los Estados a tipificar y castigar estas conductas, pero no a modificar sus reglas constitucionales y principios fundamentales relacionados con la libertad de expresión. Algunos países como el Reino Unido, Irlanda, Italia, Dinamarca o Suecia venían siendo muy reacios y lo cierto es que al amparo de esa cláusula parece que estos países podrán excluir el delito de negación del holocausto y otros genocidios si este tipo no está recogido en su ordenamiento penal y entra en conflicto con su concepción de la libertad de expresión. Una vez aprobada la Decisión-marco por el Consejo, cada país tendrá un plazo de dos años para ajustarse a las exigencias de la norma europea.

$\mathrm{El}$ acuerdo, que algunos han valorado como una rebaja sustancial respecto de la propuesta original de 2001, no incluye la prohibición de símbolos específicos como la cruz esvástica (como pretendía Alemania): no será delito si no va acompañado de incitación explícita a la violencia. Y su eficacia o alcance práctico queda un tanto diluido porque los Estados sólo estarán obligados a aplicar las sanciones cuando tales conductas se realicen «de manera que provoquen una alteración del orden público» o de forma «amenazadora, abusiva o insultante» (que inciten a la violencia en suma).

Algunos países bálticos y del este, como Polonia, Estonia, Letonia y Lituania querían que se incluyesen también expresamente la condena de los crímenes estalinistas. Finalmente, para vencer la resistencia de estos países, se acordó, en un ejercicio de equilibrismo, añadir una declaración anexa, sin valor jurídico, precisando que esta Decisión-marco no cubre todos los delitos cometidos por regímenes totalitarios, no obstante lo cual el Consejo «deplora todos esos crímenes» horribles.

Tras seis años de intenso debate y arduas negociaciones (bloqueadas prácticamente desde 2005 y reactivadas este mismo año) en torno a la penalización del racismo, un objetivo dificultado por las diferencias de tradiciones jurídicas y sensibilidades, se alcanzó un acuerdo de mínimos, algo descafeinado por las concesiones hechas para lograr el consenso. En la práctica, cada país puede mantener su actual legislación. Sólo nueve países tienen leyes específicas contra la negación del Holocausto, que aplican sobre todo Alemania y Austria.

\section{Title}

The negation of the holocaust in the jurisprudence of the European Court of Human rights: the flimsy justification of penal types contrary to the freedom of speech 


\title{
Resumen
}

Este trabajo analiza la jurisprudencia del Tribunal Europeo de Derechos Humanos relativa a la negación del Holocausto, a través de los casos relativos a Alemania, Austria y Francia. Asimismo, el trabajo aborda la difícil justificación de tipos penales contrarios a la libertad de expresión.

\begin{abstract}
Abastract
This work analyzes the jurisprudence from the European Court of Human rights relative to the negation of the Holocaust, through the relative cases to Germany, Austria and France. Also, the work approaches the difficult justification of penal types contrary to the freedom of speech.
\end{abstract}

\section{Palabras clave}

Holocausto, Libertad de expresión, Tribunal Europeo de Derechos Humanos

\section{Key words}

Holocaust, Freedom of speech, European Court of Human rights 